\title{
Limity výkonu ústavodarnej moci v Slovenskej republike (habilitačná prednáška1)
}

\section{Baraník, K.*}

BARANÍK, K.: Limity výkonu ústavodarnej moci v Slovenskej republike. Právny obzor, 104,2021 , č. 1 , s. $3-25$.

Limits of the exercise of constitutional power in the Slovak Republic. (Habilitation lecture). On the background of the existential tension between democracy and constitutionalism, the article addresses the limits of the exercise of constitutional power in the Slovak Republic. In doing so, it maps out both explicit and implicit limits of the constitutional process. First it analyses internal, i.e. national restrictions resulting from the Slovak constitutional order and then focuses to limits, the existence of which is implicitly shaped by external legal orders. Some of these restrictions on the exercise of constitutional power are quite unequivocal, others represent so far unapplied, rather hypothetical limits. The submitted text defends the need for the existence of inherent limits of the exercise of constitutional power. They are an expression of the restriction on the exercise of any power, which is the basic postulate of democratic constitutionalism. In the end of the article, the author calls for the establishment of system balance in the exercise of constitutional power of the National Council. Such approach namely supports the possibility of democratic constitutional modification and will ensure accentuation of principles of constitutionalism, without the need of fixation of the constitution to any form (implicit or explicit) of inviolability.

Key words: constitutionalism. democracy. division of power. constitutional power. limits of the exercise of constitutional power. inviolable constitutionalised provisions. implicit inviolability of constitution

\section{1 Úvod}

Koncepty demokracie a konštitucionalizmu existujú v neustálom a nezmieritel'nom napätí. Legitimita demokratického rozhodovania vychádza zo súhlasu ovládaných a je tradične stelesnená vládou väčšiny. ${ }^{2}$ Leitmotívom konštitucionalizmu je zase del'ba moci

* JUDr. Kamil B a r a n í k, PhD., LL.M. Katedra ústavného práva a právnej teórie Právnickej fakulty Univerzity Mateja Bela, Banská Bystrica.

${ }^{1}$ Habilitačná prednáška v študijnom odbore ústavné právo sa uskutočnila 10. novembra 2020 o 13 . hodine na Právnickej fakulte Univerzity Komenského v Bratislave.

${ }^{2}$ Hoci existujú mnohé modifikácie pojmu demokracia (pozri napr. FRANKENBERG, G. Democracy. In ROSENFELD, M. - SÁJO, A. (eds.). The Oxford Handbook of Comparative Constitutional Law. Oxford : Oxford University Press, 2012, s. 252 - 256) a „nie je neobvyklé nájst’ demokratický režim, v ktorom predstavitelia zákonodarného zboru reprezentujú menšinu populácie“ (BARAK, A. Sudca v demokracii. Bratislava : Kalligram, 2016, s. 57), tento príspevok bude vychádzat' z chápania demokracie ako vlády l'udu, z ktorej vyplýva väčšinové rozhodovanie. 
a ochrana základných l’udských práv. ${ }^{3}$ Primárnym prejavom konštitucionalizmu je písaná ústava, ktorej podstata tkvie v limitovaní výkonu štátnej moci. Konštitucionalizmus vyvažuje väčšinové rozhodovanie konkrétnymi systémovými poistkami (ako napr. súdny prieskum ústavnosti, postavenie opozície v parlamente, nezávislé kontrolné orgány či koncept ochrany základných práv). Tie garantujú, že práva jednotlivcov a menšín nezaniknú v rozhodnutiach väčšiny. ${ }^{4}$ Písaná ústava je teda dokumentom, ktorý na jednej strane z procesného hl'adiska garantuje vládu väčšiny, no na strane druhej zabraňuje zneužitiu moci väčšinou. Konštitucionalizmus tak obmedzuje väčšinové rozhodovanie, čím demokraciu limituje a vytyčuje mantinely jej realizácie. Konštitucionalizmus tým výkonu demokracie nasadzuje pomyselné putá. ${ }^{5}$

Ultimátnym prejavom demokracie je výkon ústavodarnej moci. Tá má vel'mi blízko k suverenite. ${ }^{6} \mathrm{~V}$ demokratickom právnom štáte je so suverenitou spojená kompetencia prvotnej normotvorby. ${ }^{7}$ Vyjadruje možnost' vytvorit' si vlastný (suverénny) právny poriadok. $\mathrm{V}$ tomto smere je však potrebné rozlišovat' politickú a právnu suverenitu. ${ }^{8} \mathrm{Od}$ čias Sieyèsa je tento rozdiel stelesnený v dichotómii ústavných mocí. Prvá z nich sa označuje ako pôvodná, resp. ustanovujúca, príp. moc ústavodarná (pouvoir constituant). Druhá sa zase nazýva odvodená, delegovaná, či ustanovená moc (pouvoir constitué). Rozdiel medzi mocou ustanovujúcou a ustanovenou je kvalitatívny a kvantitatívny. ${ }^{9}$ Podl'a historických teórií je výkon ustanovujúcej moci stotožnitel'ný s vôlou národa. Výkon originálnej moci nemožno zviazat' princípmi konštitucionalizmu. Národ stojí nad ústavou, čím je mimo dosahu právomoci štátnych orgánov..$^{10}$ Inými slovami - obmedzenia konštitucionalizmu neviažu suveréna. Vyjadrenia suverenity l’udu v čistokrvnej podobe sú však našt’astie skôr raritou. ${ }^{11}$ Neželanými sú najmä preto, že sú stelesnením neobmedzenej a často aj arbitrárnej moci, ktorá sa neriadi žiadnymi pravidlami a napokon sa môže obrátit' proti každému. ${ }^{12}$

Ústava sa často považuje za explicitný prejav činnosti originálnej ústavodarnej moci. Pritom sa akceptuje fikcia, podl’a ktorej sa práve suverén (originálna ústavodarná moc) uzniesol na základnom dokumente konkrétneho štátu. ${ }^{13}$ Ústavou tým samotný l’ud stano-

\footnotetext{
${ }^{3} \mathrm{~K}$ tomu pozri SOMEK, A. The Cosmopolitan Constitution. Oxford : Oxford University Press, 2014, s. 2 -31 .

${ }^{4}$ ELY, J., H. Democracy and Distrust. A Theory of Judicial Review. Harvard University Press, 1980, s. 81 -82 .

${ }^{5}$ ALBERT, R. Constitutional Handcuffs. In Arizona State Law Journal, 2010, roč. 42, s. 664.

${ }^{6}$ LALÍK, T. Ústavodarná moc - včera, dnes a zajtra. In Právník, 2016, č. 6, s. 512.

${ }^{7}$ HOLLÄNDER, P. Filosofie práva. 2. rozšírené vydání. Plzeň : Aleš Čeněk, 2012, s. 121.

${ }^{8}$ KYSELA, J. Ústava mezi právem a politikou. Úvod do ústavni teorie. Praha : Leges, 2014, s. 152 - 153.

${ }^{9}$ LALÍK, T. Ústavodarná moc - včera, dnes a zajtra. In Právník, 2016, č. 6, s. 512.

${ }^{10}$ SIEYÈS, E. Qu'est-ce que le Tiers état ? Paris: Éditions du Boucher, 2002, s. 53.

${ }^{11}$ Revízia ústavných textov pomocou činnosti (limitovaných) ustanovených orgánov je faktickým prejavom dočasnosti existencie originálnej ústavodarnej moci. Podl’a Gözlera ustanovujúca a ustanovená moc spolu koexistujú. Ak vykonáva činnost' jedna, potom druhá mlčí, GÖZLER, K. Pouvoir Constituant. Bursa [Turquie], Editions Ekin Kitabevi, 1999. Dostupné online na http://www.anayasa.gen.tr/pconstituant.htm\# ftn1

${ }^{12}$ Typickým prejavom originálnej moci sú revolúcie (BARANÍK, K. Ústavodarná moc a politika. In VEČĚ̌A, M. - HAPLA, M. (eds.). Weyrovy dny právni teorie. Brno : Masarykova univerzita, 2017, s. 36).

${ }^{13}$ Lalík však racionálne hovorí o tom, že ,žiadna ústava v súčasnej dobe nie je produktom akejsi plnej vnútornej suverenity konkrétneho suveréna“. L’ALÍK, T. Ústavodarná moc - včera, dnes a zajtra. In Právník,
} 
vil právomoci jednotlivých štátnych orgánov pri výkone štátnej moci, čím určil spôsob výkonu štátnej moci, t. j. výkon delegovanej moci. ${ }^{14}$ Týmto spôsobom ustanovujúca moc definuje limity ustanovených orgánov. Nasledujúci text bude nadväzovat' na naznačenú logiku duality ústavných mocí. Z jej podstaty totiž vyplýva nevyhnutnost' limitácie moci ustanovenej.

\section{2 Ústavné zmeny}

Drvivá väčšina kodifikovaných ústav (až 96 \%) dnes v svojom integrálnom texte obsahuje explicitnú zmienku o procese ústavných zmien. ${ }^{15}$ Tieto sú formalizovanými procesmi, ktorých výsledkom je modifikácia textu ustanovujúceho dokumentu. To znamená, že ústavy, t. j. produkty originálnej ústavodarnej moci, spravidla počítajú so zmenami, ktoré uskutočňujú ustanovené orgány. Inými slovami, moc originálna explicitne ráta s tým, že základný produkt jej činnosti bude modifikovaný mocou ustanovenou.

Ústavné zmeny, doplnky, dodatky, či novely, t. j. právomoc upravovat' obsah ,spoločenskej zmluvy“, resp. základnej listiny suverénneho štátu možno chápat’ ako naplnenie základnej právomoci suverénneho l'udu. Tá sa uskutočňuje v medziach originálnej delegácie. Zmena ústavného textu umožňuje zabránit' dvom nepríjemným scenárom. Prvým by bol život spoločnosti, ktorý definuje chybná, neúplná, či zastaraná ústava. Druhým nechceným scenárom by bola nevyhnutnost' ústavnej revolúcie, príp. iného spôsobu prejavenia ustanovujúcej moci pre to, aby sa začal proces tvorby ústavy nanovo. ${ }^{16}$ Možnost' zmeny ústavného textu je základným právom suveréna, a preto predstavuje esenciálnu súčast' každej ústavy. ${ }^{17}$

Niektoré ústavy však s ohl'adom na možnost' zmeny ústavného textu stanovujú výnimky. Obsahujú totiž ustanovenia, ktorých zmena je vylúčená ab initio. ${ }^{18}$ Tieto ustanovenia sa bežne označujú aj ako večné, nezmenitel'né ústavné články, či materiálne ohniská ústav. ${ }^{19}$ Existencia nezmenitel'ných ústavných článkov sa odôvodňuje viacerými spôsobmi. ${ }^{20}$ Jedným z nich je aj snaha o ochranu základných hodnôt spoločnosti, ktoré by

2016, č. 6, s. 518. Porovnaj preambulu Ústavy Slovenskej republiky „...teda my, občania Slovenskej republiky, uznášame sa prostrednictvom svojich zástupcov na tejto ústave..."

${ }^{14}$ Čl. 2 ods. Ústavy SR ,Štátne orgány môžu konat’ iba na základe ústavy, v jej medziach a v rozsahu a spôsobom, ktorý ustanovi zákon."

${ }^{15}$ GIOVANNONI, F. Amendment Rules in Constitutions. In Public Choice, 2003, roč. 115, s. 37.

${ }^{16}$ ALBERT, R. Constitutional Amendments. Making, Breaking and Changing Constitutions. New York : Oxford University Press, 2019, s. 39.

${ }^{17}$ ALBERT, R. Constitutional Handcuffs. In Arizona State Law Journal, 2010, roč. 42, s. 667.

${ }^{18} \mathrm{~K}$ historickým súvislostiam tejto diskusie pozri HOLLÄNDER, P. Filosofie práva. 2. rozšírené vydání. Plzeň : Aleš Čeněk, 2012, s. $53-65$.

${ }^{19} \mathrm{~K}$ tomu pozri prehl'ad súčasných a historických nezmenitel'ných ústavných článkov v ROZNAI, Y. Unconstitutional Constitutional Amendments. The Limits of Amendment Powers. Oxford : Oxford University Press, 2019, s. 236 - 274.

${ }^{20}$ Napr. Roznai rozlišuje 5 základných funkcií nezmenitel'ných ústavných článkov: zachovanie, transformácia, ašpirácia, konflikt, improvizácia (ROZNAI, Y. Unconstitutional Constitutional Amendments. The Limits of Amendment Powers. Oxford : Oxford University Press, 2019, s. 26 - 37), kým Albert až sedem funkcií takýchto zakotvení: uistenie, zmierenie, zachovanie, transformácia, krízový manažment, urovnanie, vyjadrenie 
podl'a názoru niektorých mali zostat' nemenné. ${ }^{21}$ Rozhodnutia prijímané v politickom procese by totiž mohli zapudit’ základné ústavné hodnoty, príp. aj samotnú ústavnú identitu. Nezmenitel'né články takúto možnost’ nepripúšt’ajú. Sú tak explicitným vyjadrením nedôvery pôvodnej ústavodarnej moci k výkonu moci ustanovenej. ${ }^{22}$ Inými slovami, matéria obsahovo pokrytá nezmenitel'ným článkom je vyňatá z dispozície demokratických procesov. Zmena je pritom možná jedine d'alším prejavom originálnej ústavodarnej moci. Na to, aby sa odstránili, či prehodnotili takto absolútne sformulované limity konštitucionalizmu, je de iure potrebná ústavná revolúcia. Nezmenitel’né články sú ultimátnym prejavom konštitucionalizmu. Z pohl'adu demokratických procesov totiž predstavujú akési neprekonatel'né limity.

Ústava, ktorá by bola ako celok nezmenitel’ná, je automatickým neúspechom..$^{23}$ Ústava totiž nemôže byt' dokonalým dielom, ktoré na „,večné veky“ stanoví základné pravidla fungovania spoločnosti. Takéto chápanie ústavy by bolo len faktickým diktátom jej tvorcov, ktorých snahou by bolo navždy „,prikovat“" nasledujúce generácie vo vlastných preferenciách. Moc menit' a doplńnat' ústavu, či dokonca prijat' úplne novú ústavu, je právomocou každého suverénna. ${ }^{24}$ Právomoc menit’ ústavu demokratickou cestou je tak možné stotožnit's fundamentálnym právom národa. ${ }^{25}$ Ústava je nikdy nekončiacim sa projektom, ktorý pokračuje a vyvíja sa, rovnako ako je to v prípade každej spoločnosti. Akokol'vek dobre myslená finalita ústavy je preto len ilúziou. Jej modifikácie nemôžu byt' v demokratickom štáte nikdy vylúčené. ${ }^{26}$

Ak zohl’adníme uvedenú, pomerne univerzálne akceptovanú premisu, ktorá sa odzrkadl'uje v dualite mocí (moc originálna v. moc delegovaná), potom aj výkon ústavodarného orgánu (ako delegovaného agenta moci originálnej) musí byt’ chápaný v limitoch sekundárnej delegácie. ${ }^{27}$ Účelom nasledujúceho textu bude práve zmapovat’ a poukázat'

hodnôt (ALBERT, R. Constitutional Amendments. Making, Breaking and Changing Constitutions. New York : Oxford University Press, 2019, s. $141-149$ ).

${ }^{21}$ Typicky čl. 9 ods. 2 Ústavy ČR, čl. 79 ods. 3 Ústavy SRN, či čl. 89 ods. 5 Ústavy Francúzska.

${ }^{22}$ ROZNAI, Y. Unconstitutional Constitutional Amendments. The Limits of Amendment Powers. Oxford : University Press, 2017, s. 17.

${ }^{23} \mathrm{~V}$ histórii možno raritne narazit’ aj na ústavy, ktoré explicitne nepripúšt’ali žiadne zmeny. Príkladom je Základná ústava kolónie Karolína sformulovaná Johnom Lockeom v roku 1669. V tejto ústave bolo vyslovene uvedené, že „všetky časti tejto ústavy sú posvätné a navždy stanovujú nezmenitelnú formu vlády Karoliny“. (ROZNAI, Y. Unconstitutional Constitutional Change by Courts. In New England Law Review, 2018, roč. 51, S. 564).

${ }^{24}$ Thomas Jefferson v tomto smere uviedol, že „mŕtvi by nemali vládnut’ živým a každá generácia má právo na novú ústavu, ktorá reflektuje realitu“. Ako však uvádzajú Klein a Sajó tento Jeffersonov výrok nenadobudol nikdy všeobecnú akceptáciu (KLEIN, C. - SAJÓ, A. Constitution-Making: Process and Substance. In ROSENFELD, M., SÁJO, A. (eds.). The Oxford Handbook of Comparative Constitutional Law. Oxford : Oxford University Press, 2012, s. 437). Naopak, James Madison sa snažil čo najviac zachovat' nemennost' pôvodnej ústavy (K tomu bližšie HAMILTON, A. - MADISON, J. - JAY, J. Listy federalistov. Bratislava : Kalligram, 2002, s. $392-397$ (List č. 49).

${ }^{25}$ ALBERT, R. Constitutional Amendments. Making, Breaking and Changing Constitutions. New York : Oxford University Press, 2019, s. $194-195$.

${ }^{26}$ Ibid., s. 255.

${ }^{27}$ Tento rozdiel sa odvodzuje od už spomenutého francúzskeho revolucionára Sieyèsa. Zásadne si ho všíma aj Schmitt ako rozdiel medzi ústavodarnou mocou nemeckého národa a právomocou Reichstagu podl'a 
na limity výkonu ústavodarného orgánu v Slovenskej republike. Aj ked’ sa to na prvý pohl'ad nemusí tak javit', Národná rada SR (d’alej len národná rada) konajúca v rozsahu vlastnej ústavnej delegácie, je obmedzená viacerými explicitnými a implicitnými limitmi. Ich existencia a potenciál bude predmetom nasledujúceho textu. Ciel'om príspevku je demonštrovat', že slovenský konštitucionalizmus určuje demokratickým procesom limity, ktoré nie je oprávnený prekročit' ani samotný ústavodarný orgán.

\section{Výkon ústavodarnej právomoci Národnej rady SR}

Podl'a čl. 72 je národná rada jediným ústavodarným a zákonodarným orgánom Slovenskej republiky. Národná rada má právomoc uznášat' sa na ústave, ústavných a ostatných zákonoch (čl. 86 písm. a). No a napokon na prijatie ústavy, zmenu ústavy, ústavného zákona...je potrebný súhlas aspoň trojpätinovej väčšiny všetkých poslancov národnej rady (čl. 84 ods. 4). To sú základné náležitosti prijímania ústavných zmien, príp. aj pravidla pre prijatie úplne novej ústavy cestou ústavodarného procesu v národnej rade. $V$ texte ústavnej úpravy tak nie je možné nájst' vel'a rozdielov medzi bežným zákonodarným a ústavodarným procesom. Jediným zásadným rozlišovacím faktorom je $\mathrm{v}$ tomto smere počet poslancov, ktorí musia hlasovat' za prijatie návrhu ústavného a bežného zákona. Poslanci národnej rady tak pri svojej činnosti nosia pomyselné „dva plášte“. Jedným sa odievajú, ked' vykonávajú ústavodarnú moc a tým druhým, ked' uplatňujú zákonodarnú právomoc. Rozdiel medzi týmito činnost’ami nie je len procesný, ale predovšetkým materiálny. Kvalitatívny rozdiel medzi výkonom týchto dvoch právomocí je zásadný, a to aj napriek tomu, že z politického hl'adiska sa zvykne redukovat' práve len na formálny rozdiel v počte poslaneckých hlasov potrebných na ich uplatnenie.

Väčšina slovenskej právnej doktríny sa dlhodobo zväčša zhoduje na tom, že ústavodarca $\mathrm{v}$ ústavnom texte explicitne nevyjadril žiadne limity ${ }^{28}$ výkonu právomoci jediného ústavodarného orgánu. ${ }^{29} \mathrm{Na}$ rozdiel od politickej arény, kde sa vzhl’adom na ústavodarný proces zväčša len chladnokrvne politicky kalkuluje, sa však o podstate tejto limitácie v právnej doktríne neustále živo diskutuje. Predmetom týchto akademických úvah sa stala práve otázka, či je ústavodarný orgán pri výkone ústavodarnej právomoci aspon̆ implicitne obmedzený. Veda ústavného práva sa prikláňala k existencii určitých materiálnych limitov, čím sa snaží vyvrátit’ tézu o nespútanej moci väčšinového, t. j. demokratického rozhodovania. ${ }^{30}$ Tým podporuje tézu limitácie výkonu moci. Akademici sa teda

čl. 76 weimarskej ústavy. Táto delegácia nie je všemocná a inherentne obsahuje limity. Ústavodarná moc l'udu a právomoci ústavodarného orgánu sú dve kvalitatívne odlišné kategórie (SCHMITT, C. Constitutional Theory. Durham a Londýn : Duke University Press, 2008, s. 74, 79 - 80).

${ }^{28}$ Napr. SVÁK, J. - BALOG, B. Hlasovanie l'udu v referende a vo vol'bách z pohl'adu nezmenitel'ných náležitosti ústavy. In OROSZ, L. - MAJERČÁK, T. a kol. Aktuálne problémy volebného práva - nové volebné zákony - IV. ústavné dni. Košice, 2015, s. 96 - 97.

${ }^{29}$ Niektorí akademici však tvrdia opak. Napr. PROCHÁZKA, R. L’ud a sudcovia v konštitučnej demokracii. Plzeň : Aleš Čeněk, 2011, s. 47 - 48; KÁČER, M. - NEUMANN, J. Materiálne jadro v slovenskom ústavnom práve. Doktrinálny disent proti zrušeniu sudcovských previerok. Praha : Leges, 2019, s. 132 - 133.

${ }^{30}$ Dokonale sformulovanou v téze politikov: „Vyhraj vol'by a môžeš všetko.“ 
v prevažnej väčšine stavajú na stranu existencie implicitných limitov výkonu štátnej moci, a to vrátane činnosti ústavodarného orgánu. ${ }^{31}$

Ústava na prvý pohl'ad skutočne nevytvára žiadne procesné a ani substantívne limity výkonu ústavodarnej právomoci národnej rady. Je však možné nazdávat' sa, že takéto limity predsa len existujú. A to nielen implicitné, ale aj explicitné. V tomto smere je, samozrejme, nevyhnutné vziat' do úvahy viac ako len samotný text ústavy. Ústavná prax a komparatívne skúsenosti v tomto smere poodhal'ujú možnosti existencie d'alších ústavných limitov, ktorých pôvod sa nachádza aj v sférach mimo slovenského ústavného poriadku. Doteraz však tieto limity nevzbudzovali náležitú, resp. takmer žiadnu pozornost. ${ }^{32}$

Tak ako je pre ústavné právo typické, mnohé jeho súčasti sú tvorené nepísanými a logicky previazanými súvislost’ami. Ústava moderného štátu nie je akousi vyčerpávajúcou príručkou, ktorá má mat' ambíciu poskytnút' odpoved' na každú otázku, aká sa v živote spoločnosti môže vyskytnút'. Obdobne to platí aj s ohl'adom na existenciu ústavných limitov, na ktoré sa v mnohých ohl'adoch vzt'ahujú vnútorné súvislosti, ktoré v explicitnom ústavnom texte nie je možné nájst'. Pre prehl'adnost' d’alšej argumentácie budú ústavné limity rozdelené na procesné a materiálne. Druhej skupine bude z pochopitel'ných dôvodov venovaný väčší priestor, ked’že práve do nej spadá väčšina zmienených obmedzení výkonu ústavodarného orgánu. V tejto kategórii sa napokon stretneme aj s limitmi, ktoré svoj pôvod majú mimo slovenského ústavného poriadku.

\section{Procesné limity výkonu ústavodarnej moci}

Základný procesný limit čl. 84 ods. 4 prijímania ústavných zákonov, resp. celej novej ústavy bol už vyššie naznačený. K tomu treba dodat', že ústava do výkonu ústavodarnej právomoci nezapája žiadne iné orgány, a to ani vo forme konzultácie. ${ }^{33} \mathrm{~V}$ tomto smere je

\footnotetext{
${ }^{31}$ Niektorí autori tvrdili, že národná rada môže prijímat' len ústavné zákony, na ktoré existuje explicitné ústavné splnomocnenie (napr. BREICHOVÁ LAPČÁKOVÁ, M. Neústavné ústavné zákony? - I. čast'. In Justičná revue. 2011, roč. 63, č. 1, s. 1 - 15; BREICHOVÁ LAPČÁKOVÁ, M. Neústavné ústavné zákony? II. čast'. In Justičná revue. 2011, roč. 63, č. 2, s. 181 - 192). Iní zase nachádzali implicitné limity v „duchu ústavy“ (napr. BALOG, B. Materiálne jadro Ústavy Slovenskej republiky. 1. vydanie. Žilina : Eurokódex, 2014, s. 71 - 107; L'ALÍK, T. Ústavný súd a parlament v konštitučnej demokracii. Bratislava : Wolters Kluwer, 2015, s. 92 - 97; DRGONEC, J. Základné práva a slobody a vyvodená pôsobnost' Ústavného súdu SR. In OROSZ, L. - MAJERČÁK, T. a kol. Ochrana l’udských práv a základných slobôd ústavnými súdmi a medzinárodnými súdnymi orgánmi - III. ústavné dni. Košice, 2014, s. 177 - 178; BARANÍK, K. Ústavodarná moc a politika. In VEČĚ̌A, M. - HAPLA, M. (eds.). Weyrovy dny právní teorie. Brno : Masarykova univerzita, 2017, s. 43 - 47). Stretnút' sme sa však mohli aj s opačnými názormi, ktoré akcentovali striktnú legalitu výkonu ústavných právomocí (PROCHÁZKA, R. L’ud a sudcovia v konštitučnej demokracii. Plzeň : Aleš Čeněk, 2011, s. $31-36)$.

${ }^{32} \mathrm{~V}$ tomto smere však možno nájst' aj výnimky. Napr. PROCHÁZKA, R. L’ud a sudcovia v konštitučnej demokracii. Plzeň : Aleš Čeněk, 2011, s. 122.

${ }^{33}$ Skutočnost', že ústavodarný proces je zverený jedinému orgánu, ktorý je sám ustanoveným orgánom (nejde teda o špecifické ústavodarné zhromaždenie vytvorené ad hoc na účely ústavodarného procesu), je problematický. Má totiž tendenciu, ktorá smeruje k zneuživaniu tejto právomoci. LANDAU, D. Democratic Erosion and Constituion-Making Moments. In UC Irvine Journal of International, Transnational and Comparative Law, 2017, roč. 2, s. $98-99$.
} 
preto možné povedat', že aj ked' ústava del'bu moci nepochybne považuje za implikovanú samozrejmost ${ }^{34}$, pri výkone ústavodarnej moci jednoducho neexistuje. $\mathrm{V}$ tomto smere je explicitne oslabená výkonná moc (nemožnost’ uplatnenia prezidentského veta ${ }^{35}$ ), ako aj moc súdna (nemožnost' prieskumu ústavnej súladnosti ,produktov“ uplatnenej ústavodarnej právomoci $\left.{ }^{36}\right)$.

Týmto spôsobom je národnej rade zverená ohromná právomoc. Vo väčšine demokratických krajín sa ústavodarný proces uskutočňuje aspoň v režime čiastočnej medzi-inštitucionálnej spolupráce (napr. potreba schválenia ústavnej zmeny prezidentom alebo následná nevyhnutnost' prelomenia kvalifikovaného veta), príp. vnútrosystémovej kolaborácie (napr. potreba schválenia dvomi parlamentnými komorami, či nevyhnutnost' opätovného parlamentného schválenia návrhu ústavného zákona po vol'bách). ${ }^{37} \mathrm{~V}$ komparatívnej ústavnej praxi je taktiež možné stretnút' sa s rozdielom medzi prijímaním úplne novej ústavy, či „len“ ústavných modifikácii. ${ }^{38}$ Taktiež je možné nájst' aj tzv. stupňovité (hierarchické) kategorizovanie ústavného textu, ktoré nadväzuje na formálne odlišné procedúry zmeny rozdielnych častí ústavy (najdôležitejšie časti ústavného textu zvyčajne podliehajú najkomplikovanejším ústavným procedúram, a preto je im v danom ústavnom systéme zväčša prisudzovaná najvyššia sila $\left.{ }^{39}\right)$. Zo slovenského ústavodarného procesu je taktiež úplne vylúčený l'ud. Dokonca aj ak by boli občania úspešní pri schval'ovaní ústavných zmien $\mathrm{v}$ referende, aj vtedy by mala finálne slovo o podobe ústavnej zmeny národná rada $\mathrm{v}$ „klasickom“ ústavodarnom procese. ${ }^{40}$

Ústava je pri ústavných zmenách extrémne striktná a nenachádza sa v nej akékol’vek procesné obmedzenie, či zvýšená rigidita. Rovnaká ústavná procedúra platí pre akúkol'-

${ }^{34}$ DRGONEC, J. Ústava Slovenskej republiky. Teória a prax. 2. prepracované a doplnené vydanie. Bratislava : C. H. Beck, 2019, s. 177.

${ }^{35}$ Ústavným zákonom č. 9/1999 Z. z. bola prezidentovi odňatá možnost' vetovat’ ústavný zákon a vrátit’ ho Národnej rade SR na opätovné prerokovanie. Táto procedurálna poistka pri tom nebola ničím nahradená, napr. potrebou kvalifikovaného prelomenia prezidentského veta, ktoré by s ohl'adom na procesné podmienky prijímania ústavných zákonov dávali zmysel a aspoň formálne by st’ažovali ústavodarný proces.

${ }^{36}$ Čl. 125 ods. 1 neumožňuje Ústavnému súdu skúmat’ súlad ústavy a ústavných zákonov. Modifikáciu tohto vzt'ahu priniesol až PL. ÚS 21/2014.

${ }^{37}$ Pre komparatívne alternatívy ústavodarného procesu pozri napr. LIJPHART, A. Patterns of Democracy. Government Forms and Performance in Thirty-Six Countries. Second Edition. New Haven \& London : Yale University Press, 2012, s. 204 - 225; ALBERT, R. Constitutional Amendments. Making, Breaking and Changing Constitutions. New York : Oxford University Press, 2019, s. 95 - 138; LUTZ, D., S. Principles of Constitutional Design. Cambridge : Cambridge University Press, 2006, s. $157-170$.

${ }^{38}$ Carl Schmitt v tomto smere hovorí o ústavnom zničení, ústavnej eliminácii, ústavnej zmene a ústavnom suspendovaní (SCHMITT, C. Constitutional Theory, Durham a Londýn: Duke University Press, 2008, s. 147 - 166). Ústavy Rakúska, Kostariky, Španielska a Švajčiarska explicitne stanovujú rozdielnu procedúru pre prijímanie novej ústavy a pre prijímanie ústavných noviel. Ústavy Kapverd a Uruguaja taktiež rozlišujú medzi prijímaním novej ústavy a prijímaním ústavnej novely, avšak nezakotvujú rozdielne procedúry na ich prijímanie (ALBERT, R. The Structure of Constitutional Amendment Rules. In Wake Forest Law Review, 2014, roč. 49, s. $930-935)$.

${ }^{39}$ Napr. Ústavný zákon Kanady (1982) rozoznáva viacero (aspoň 5) vzájomne sa vylučujúcich spôsobov prijímania ústavných noviel (K tomu detailne ALBERT, R. The Difficulty of Constitutional Amendment in Canada. In Alberta Law Review, 2015, roč. 53, s. 85 - 114).

${ }^{40}$ Pri možnosti priameho účinku výsledku platného referenda existujú aj na Slovensku viaceré nevyriešené polemiky. K tomu pozri napr. GIBA a kol. Ústavné právo. Bratislava : Wolters Kluwer, 2019, s. 219 - 226. 
vek zmenu. Z procesného hl'adiska je tak modifikácia jediného slova v akejkol’vek časti ústavy (napr. aj v dôsledku jazykovej chyby) rovnako náročným procesom, akým je proces prijatia textu úplne novej ústavy. Na základe tejto formalistickej logiky, ktorú predurčuje ústavný text, sme v našich podmienkach už boli svedkami postupov, ktoré sa dajú pomerne jednoznačne kategorizovat' ako ústavná neúcta, či ich dokonca označit' ako pohŕdanie ústavou. Príkladom nech je ústavodarný proces prijímania ústavného zákona č. 356/2011 Z. z., ktorý na pomerne zásadné modifikovanie textu ústavy, týkajúce sa postavenia prezidenta, potreboval jediný deň. ${ }^{41}$ Takýto prístup redukuje deliberáciu, participáciu, či kolaboráciu pri ústavodarnom procese na absolútne minimum. Napriek tomu, že sa takýmto spôsobom k ústave pristupovat' môže, nemalo by sa to robit'. Od potenciálnej ústavnej katastrofy nás tak delí jedine vôl'a 90 poslancov národnej rady, ktorí sa pri absencii akýchkol'vek limitov stávajú de facto suverénom. ${ }^{42}$

Napriek uvedenému sa však v slovenskom ústavnom poriadku predsa len nachádza procesný limit. Nie však v integrálnom ústavnom texte, ale $\mathrm{v}$ samostatne stojacom ústavnom zákone. Pomerne jasne formulovaný (t. j. explicitný) procesný limit ústavodarnej právomoci možno nájst' v ústavnom zákone č. 227/2002 Z. z. o bezpečnosti štátu. ${ }^{43}$ Toto obmedzenie sa týka pôsobenia Parlamentnej rady SR, ktorá v zmysle čl. 7 tohto ústavného zákona v čase vojny, vojnového stavu alebo výnimočného stavu vykonáva ústavné právomoci národnej rady, ak je jej činnost' znemožnená. Výnimkou $\mathrm{v}$ tomto smere je však aj prijímanie ústavy a ústavných zákonov ${ }^{44}$. Ústavodarný proces sa tak nemôže na pôde Parlamentnej rady ani len začat'. Národná rada je tak skutočne jediným orgánom, v ktorom sa môže legálnym spôsobom zmenit’ ústava. Substitúcia tohto orgánu je ústavnoprávne vylúčená. Uvedený limit výkonu ústavodarnej moci sa tak netýka národnej rady. Práve naopak, toto obmedzenie koncentruje ústavodarnú právomoc jedine na pôdu národnej rady, čím jej dominanciu v tomto procese len d'alej zvýrazňuje.

${ }^{41}$ Jeden deň je v tomto smere dokonca ešte „láskavé“ meranie času. Celkové schval'ovanie parlamentnej tlače č. $548 \mathrm{v}$ piatom volebnom období národnej rady, z ktorej napokon vzišiel tento ústavný zákon, sa začalo 21. 10. 2011 prvým čítaním o 17.14 a skončilo sa finálnym hlasovaním v tret’om čítaní v ten istý deň o 17.49. Reálny čas tohto ústavodarného procesu sa tak scvrkáva na 35 minút, čo je naozaj len t’ažko uveritel'né. Za finálny návrh tohto ústavného zákona pritom hlasovalo 139 z prítomných 140 poslancov. Tento ústavný zákon navyše nadobudol účinnost' dňom vyhlásenia. Je náročné predstavit' si väčšiu neúctu k ústavodarného procesu, či hrubšiu úroveň ignorancie ústavného textu. Politickí reprezentanti, ktorí každoročne 1. septembra tak radi rečnia o úcte $\mathrm{k}$ ústave, týmto konaním demonštrovali hlbokú neúctu k základnému dokumentu nášho štátu. Informácie o tomto ústavodarnom procese sú dostupné online https://www.nrsr.sk/web/Default.aspx?sid=scho$\mathrm{dze} / \mathrm{hlasovanie} /$ vyhladavanie_vysledok\&ZakZborID $=13 \&$ CisObdobia $=5 \& \mathrm{Text}=\& \mathrm{CPT}=548 \&$ CisScho$\mathrm{dze}=\&$ DatumOd $=\&$ DatumDo $=\&$ FullText $=$ False

${ }^{42}$ BARANÍK, K. Ústavodarná moc a politika. In VEČEǨA, M. - HAPLA, M. (eds.). Weyrovy dny právní teorie. Brno : Masarykova univerzita, 2017, s. 36 - 39.

${ }^{43}$ Niektorí autori takéto obmedzenia nazývajú aj nezmenitel’nými ústavnými klauzulami v časoch krízového manažmentu. K tomu pozri ALBERT, R. Constitutional Amendments. Making, Breaking and Changing Constitutions. New York : Oxford University Press, 2019, s. 147 - 148, 203.

${ }^{44}$ Čl. 7 ods. 2 písm. a) ústavného zákona č. 227/2002 Z. z. 


\section{Substantívne limity výkonu ústavodarnej moci}

V porovnaní s formálnymi procesmi predstavujú substantívne požiadavky na ústavodarný proces d'aleko väčší okruh obmedzení. Existencia niektorých z nich je výsledkom aplikácie implicitnej logiky, niektoré boli už explicitne deklarované, iné sú špekulatívnejšieho charakteru. Všetky však vychádzajú z ústavného (kon)textu. Predstavujú pomerne pestrú paletu obmedzení, na ktorú by mal ústavodarný orgán prihliadat' pri svojej činnosti.

Na úvod je vhodné rozdelit’ tieto limity do dvoch kategórií. Prvou sú (a) interné substantívne limity, ktoré vychádzajú výlučne z medzí slovenského právneho poriadku. Druhou kategóriou sú (b) externé limity. Tie sa vo svojej podstate taktiež opierajú o charakter a vnútornú koherenciu slovenského právneho poriadku, no ich argumentačné jadro sa nachádza v externých právnych sférach.

\section{a) Interné limity}

Tieto obmedzenia výkonu ústavodarnej moci primárne vychádzajú z konceptu delegovania moci. Sekundárne sa opierajú o princíp suverenity, ktorý deklaruje, že suverenitu smerom dovnútra nie je možné obmedzit'.

Prvý z interných limitov je explicitne vyjadrený v čl. 99 ods. 1. V tomto prípade nejde o limitáciu ústavodarného procesu vo vzt’ahu k textu ústavy, ale o obmedzenie ústavodarcu smerujúce $\mathrm{k}$ materiálnej podstate výsledkov úspešného referenda. Tieto môže národná rada zmenit' alebo zrušit' jedine ústavným zákonom, avšak až po uplynutí troch rokov od ich účinnosti. Ústava teda garantuje ochrannú lehotu, tzv. temporálnu nezmenitel'nost' výsledkov (t. j. obsahu) platného referenda. Akékol'vek porušenie tejto lehoty by bolo nelegálne. Nič by na tom nezmenilo ani jednomysel'né hlasovanie poslancov národnej rady. Niektorí autori sa nazdávajú, že táto lehota („od účinnosti výsledku referenda“) začína plynút' momentom zverejnenia výsledkov referenda v Zbierke zákonov SR. ${ }^{45}$ $\mathrm{S}$ ohl'adom na doterajšiu judikatúru ústavného súdu ${ }^{46}$ by však bolo racionálne interpretovat' „účinnost' úspešného referenda“ a rátat' ju od momentu, ked' sa právne účinky referenda reálne prejavia $\mathrm{v}$ právnom poriadku. Národná rada, ktorá má ústavný mandát, príp. pozitívny záväzok prijat' náležitú právnu úpravu, a tým rešpektovat' výsledok úspešného referenda ${ }^{47}$, by totiž mohla prijatie náležitých právnych predpisov dlhodobo blokovat'. Či už úmyselne alebo neúmyselne by takýmto konaním mohol parlament skracovat' ústavnú ochrannú lehotu právnych účinkov výsledkov platného referenda.

Druhý explicitný interný limit výkonu ústavodarnej moci, ktorý je dlhodobo pomerne nepochopitel’ne prehliadaný právnou doktrínou, ale aj samotným Ústavným súdom, je

${ }^{45}$ DRGONEC, J. Ústava Slovenskej republiky. Teória a prax. 2. prepracované a doplnené vydanie. Bratislava : C. H. Beck, 2019, s. 1270.

${ }^{46}$ Najmä II. ÚS 31/97 a PL. ÚS 24/2014.

${ }^{47}$ Výnimkou z pozitívneho záväzku by mohli byt' prípadné automatické účinky vyhlásených výsledkov referenda ako osobitného prameňa práva. GIBA, M. a kol. Ústavné právo. Bratislava : Wolters Kluwer, 2019, s. $223-226$. 
nezmenitel’ný ústavný článok. Napriek tomu, že sa tradične uvádza, že Ústava SR takéto ustanovenia neobsahuje, možno poukázat’ na druhú vetu čl. 12 ods. $1^{48}$. Potenciálne „nezrušitel'nú “ formuláciu tohto ustanovenia si už však všimlo niekol'ko autorov. ${ }^{49}$ Nevedno prečo na ňu Ústavný súd doteraz podstatným spôsobom neprihliadol. Pomerne zarážajúco táto skutočnost' vyznieva najmä s ohl'adom na rozhodnutie, v ktorom Ústavný súd „objavil“ existenciu implicitného materiálneho jadra. Avšak na úplne inom mieste ústavného poriadku. ${ }^{50}$

Nasledujúce interné limity sú už obmedzeniami implicitnými. Vychádzajú z podstaty ústavného práva, v ktorom často úmyselne absentuje explicitnost' a definičnou črtou jeho ustanovení je skôr otvorená textúra ako detailná právna regulácia. ${ }^{51} \mathrm{Na}$ Slovensku sa doteraz ústavná obyčaj nestala podstatným prameňom ústavného práva ${ }^{52}$, preto sa $\mathrm{v}$ nasledujúcom texte nebude d'alej rozoberat'. Podstatnejšími sú v tomto smere predovšetkým implikované pravidlá, ktoré sú nevyhnutnou nadstavbou explicitného ústavného textu. Zachovávajú totiž vnútornú logiku a vzájomnú súdržnost’ jednotlivých článkov ústavy. ${ }^{53}$

Pri prijímaní bežných zákonov je národná rada inherentne obmedzená ústavnými obsahovými limitmi, ktoré má Ústavný súd právomoc skúmat' v abstraktnom konaní o súlade právnych predpisov. Inými slovami, aj napriek absencii takéhoto príkazu môže národná rada prijímat' len ústavne súladné zákony. Inak riskuje deklaráciu ich neústavnosti. Kvalitatívne tak všetky zákony musia spíňat’ obsahovú požiadavku ústavného súladu. Ked'že ústava určitý obsah priamo nariad’uje alebo vylučuje, implicitne určuje materiálny rámec celého právneho poriadku. ${ }^{54}$ Pri ústavodarnej činnosti však takéto obsahové limity neexistujú. ${ }^{55} \mathrm{Z}$ povahy veci však určité limity ústavodarného orgánu existovat' musia. Ústava totiž z obsahového hl'adiska musí spĺn̆at' aspoň základné kvalitatívne

${ }^{48}$ „Základné práva a slobody sú neodňatelné, nescudzitelné, nepremlčatel'né a nezrušitel'né. “

${ }^{49}$ Napr. PROCHÁZKA, R. L’ud a sudcovia v konštitučnej demokracii. Plzeň : Aleš Čeněk, 2011, s. 47 - 48.

${ }^{50}$ KÁČER, M. - NEUMANN, J. Materiálne jadro v slovenskom ústavnom práve. Doktrinálny disent proti zrušeniu sudcovských previerok. Praha : Leges, 2019, s. 133 - 134.

${ }^{51}$ HART, H., L., A. Pojem práva. Praha : Prostor, 2004, s. 27. K tomu pozri aj KYSELA, J. Ústava mezi právem a politikou. Úvod do ústavni teorie. Praha : Leges, 2014, s. $54-62$.

${ }^{52}$ Problematickými sú oba tradičné komponenty existencie ústavnej obyčaje. Ako opinio necessitatis, tak aj usus longaevus. Bližšie DRGONEC, J. Ústava Slovenskej republiky. Teória a prax. 2. prepracované a doplnené vydanie. Bratislava : C. H. Beck, 2019, s. $67-70$.

${ }^{53}$ Ústavný súd pri interpretácii jednotlivých ustanovení ústavy dlhodobo racionálne akcentuje chápanie „ústavy ako celku“. Podl'a stabilizovanej judikatúry ústava predstavuje právny celok, ktorý treba aplikovat’ vo vzájomnej súvislosti všetkých ústavných noriem. Len výnimočne a ojedinele môže nastat’ stav, ked’ sa spoločensky upravený vzt’ah upravuje jedinou normou ústavy (II. ÚS 128/95). Každé ustanovenie ústavy treba interpretovat' a uplatňovat' v nadväznosti na iné normy ústavy, pokial' existuje medzi nimi príčinná súvislost' (II. ÚS 48/97), a preto Ústavný súd opakovane vyslovil názor, že ustanovenia ústavy sa vysvetlujú a uplatňujú vo vzájomnej súvislosti všetkých relevantných noriem (II. ÚS 31/97, PL. ÚS 13/97, PL. ÚS 15/98, II. ÚS 10/99, I. ÚS 53/01, atd'.).

${ }^{54}$ KELSEN, H. Pure Theory of Law. $5^{\text {th }}$ print. Berkeley: University of California Press, 2008, s. $198-201$.

${ }^{55}$ Podobne argumentuje Procházka, ked’ čl. 86 písm. a) považuje za generálnu blanketu na vydávanie ústavných zákonov PROCHÁZKA, R. Lud a sudcovia v konštitučnej demokracii. Plzeň : Aleš Čeněk, 2011, s. $22-23$. 
kritériá, ináč celá koncepcia ústavy ako normy noriem daného právneho poriadku stráca akýkol’vek význam. Ústava totiž nie je základným dokumentom štátu len preto, že národná rada týmto spôsobom označí l'ubovol'ný text. Ad absurdum totiž nie je vylúčené, že národná rada ústavou predpísaným spôsobom schváli, že aktuálny jedálny lístok v parlamentnej jedálni, prípadne text náhodne zvolenej piesne, bude Ústavou Slovenskej republiky. V tomto smere je možné očakávat' zhodu na tom, že takéto absurdné prípady by nemohli viest' k tvorbe ústavy. A to aj napriek tomu, že ústavný text nič podobné explicitne nevylučuje. Implicitne to však možné nie je. Základné predpoklady pre to, aby sa takéto texty stali ústavou suverénneho štátu, jednoducho nie sú splnené. Čl. 16 Deklarácie práv človeka a občana z roku 1789 v tomto smere vel'mi výstižne uvádza: „Spoločnost', v ktorej nie je zabezpečená záruka práv ani vytvorená del'ba moci, nemá vôbec ústavu. "Garancia práv a slobôd, ako aj princíp del'by moci sú kl'účové pre každú ústavu, a to bez ohl'adu na jej formu (písanú alebo nepísanú). Navyše, každá ústava potrebuje pre svoju existenciu akceptáciu, t. j. legitimitu, tých, na ktorých sa tento dokument bude vzt'ahovat' (procedurálna a hodnotová legitimita ${ }^{56}$ ). Ústavodarný orgán je v tomto smere nepochybne implicitne limitovaný.

Podl'a niektorých názorov právnej doktríny je d’alším implicitným limitom ústavodarnej moci, a to najmä originálnej ústavodarnej moci, nevyhnutnost’ existencie možnosti opätovnej realizácie ustanovujúcej moci. Inými slovami, ustanovujúca (pôvodná) moc nemôže vylúčit' opätovnú reaktiváciu ustanovujúcej moci. Ide o analogickú zásadu, akú poznáme z konceptu parlamentnej suverenity, podl'a ktorej parlament môže teoreticky všetko s výnimkou viazania d'alšieho parlamentu. ${ }^{57}$ Viacerí autori v tomto smere hovoria o základnom katalógu práv (najmä sloboda slova), prostredníctvom ktorého sa ustanovujúca moc $\mathrm{v}$ demokratickom právnom štáte realizuje. ${ }^{58}$ Pôvodná ústavodarná moc musí teda mat' možnost' opätovne sa prejavit'. Aktuálna ústavodarná, či ustanovená moc takéto prejavy nemôžu definovat' $\mathrm{v}$ termínoch ilegality. Takáto deklarácia by sa rovnala tautológii. ${ }^{59}$

Napokon, finálny implicitný interný limit činnosti slovenského ústavodarného orgánu nájdeme $\mathrm{v}$ implicitnom materiálnom jadre. Jeho existenciu deklaroval Ústavný súd 30. januára 2019 v rozhodnutí PL. ÚS 21/2014. Podl'a odôvodnenia rozhodnutia (i) základ implicitného materiálneho jadra ústavy tvoria princípy demokratického a právneho štátu a medzi nimi aj princíp del'by moci a s ním súvisiaca nezávislost' súdnej moci. (ii)

${ }^{56}$ HOLLÄNDER, P. Základy všeobecné státovědy. 3. vydání. Plzeň : Aleš Čeněk, 2012, s. 61.

${ }^{57}$ GOLDSWORTHY, J. Parliamentary Sovereignty: Contemporary Debates. Cambridge : Cambridge University Press, 2010.

${ }_{58}$ ALBERT, R. Constitutional Amendments. Making, Breaking and Changing Constitutions. New York : Oxford University Press, 2019, s. $199-200$.

${ }^{59}$ Aj ked' sa explicitné ústavné vylúčenie tzv. ústavnej revolúcie môže zdat' až nepredstavitel'né, možno v tomto smere uviest' príklad Ústavy Mexika (1917). Tá v hlave IX, čl. 136 zakotvuje svoju vlastnú nenahraditel'nost'. Takéto ustanovenie, vynútené historickou skúsenost'ou s opakovaným rebéliami (t. j. revolúciami), vylučuje legálnu cestu prijatia novej ústavy. Obsahovo podobné články nájdeme aj v iných latinskoamerických ústavách (napr. čl. 375 Ústavy Hondurasu, či čl. 137 Ústavy Paraguaja). K tomu ALBERT, R. Four Unconstitutional Constitutions and their Democratic Foundations. In Cornell International Law Journal, 2017, roč. 50, s. $189-196$. 
Implicitnému materiálnemu jadru ústavy nemôžu odporovat’ ani ústavné zákony. A napokon (iii) Ústavný súd je oprávnený preskúmat’ prípadný rozpor noriem ústavného zákona s implicitným materiálnym jadrom ústavy a ak zistí rozpor, je oprávnený vyslovit’ nesúlad noriem ústavného zákona s implicitným materiálnym jadrom ústavy ${ }^{60}$

Na rozdiel od limitov, ktoré už boli spomenuté, je obmedzenie ústavodarného orgánu implicitným materiálnym jadrom ústavy vynútitel’né rozhodovacou činnostou ústavného súdnictva. Týmto rozhodnutím Ústavný súd ukončil akademickú debatu o hypotetických implicitných limitoch výkonu právomoci ústavodarného orgánu. Tým, že sa podujal chránit' ústavnost' aj proti samotnému ústavodarnému orgánu, vyjadril sprostredkovanú nedôveru vo vzt’ahu k demokratickým procesom a v podstate aj samotnému suverénovi. Kandidáti na politických reprezentantov totiž môžu deklarovat' neskrývanú ambíciu uchádzat' sa o poslanecký mandát práve s úmyslom zasiahnut', zmenit' či úplne odstránit' tie časti ústavy, ktoré spadajú do sféry nejasne sformulovaného implicitného materiálneho jadra slovenskej ústavy. Ani prípadná drvivá podpora občanov týchto reprezentantov však podl'a ústavného súdu nemôže stačit' na zmenu ustanovení spadajúcich do materiálneho jadra ústavy. Na základe tohto rozhodnutia sú totiž niektoré časti ústavy mimo dosah „politickej arény“, a teda aj demokratickej diskusie. Ústavný súd totiž až do prípadnej ústavnej revolúcie uzavrel možnosti akýchkol’vek zmien, ktoré spadajú do vytýčené implicitného materiálneho jadra ústavy. Imaginárne tým hodil pomyselné klúče demokratickej ústavnej zmeny „na dno oceánu“. V rozsahu deklarovanej ústavnej nezmenitel'nosti odňal Ústavný súd občanom suverenitu. ${ }^{61}$

Odňatie práva l'udu určovat' si vlastný osud sa Ústavný súd snažil moderovat' v bode 177 tohto rozhodnutia. Uvedený ,ústupok“ v podobe možnosti zmenit’ materiálne jadro v platnom referende je však zmätočný, nelogický a v konečnom dôsledku de facto neaplikovatel'ný. Išlo pravdepodobne skôr o formálnu snahu zjemnit' tak zásadné vyslovenia nedôvery $\mathrm{v}$ demokratické procesy. ${ }^{62}$

\section{b) Externé limity}

Druhou kategóriou limitov výkonu ústavodarnej moci, o ktorých sa však na Slovensku málokedy diskutuje, sú limity externé. Ide o obmedzenia, ktorých substantívna podstata „,prichádza“ do národného právneho poriadku z externého priestoru. Nezohl'adňuje sa pri tom, či ide o porovnávanie ustanovenej alebo ustanovujúcej moci, podstatná je „kompatibilita“ s nadnárodným priestorom, resp. s medzinárodnými štandardmi. ${ }^{63}$

${ }^{60}$ Bod 169 rozhodnutia.

${ }^{61}$ ALBERT, R. Constitutional Handcuffs. In Arizona State Law Journal, 2010, roč. 42, s. 676.

${ }^{62} \mathrm{~K}$ tomu bližšie KÁČER, M. - NEUMANN, J. Materiálne jadro v slovenskom ústavnom práve. Doktrinálny disent proti zrušeniu sudcovských previerok. Praha : Leges, 2019, s. 119 - 131. Pre opačný názor pozri L'ALÍK, T. The Slovak Constitutional Court on Unconstitutional Amendment (PL. ÚS 21/2014) In European Constitutional Law Review, 2020, roč. 16, č. 2, s. 337 - 340.

${ }^{63}$ LANDAU, D. E. - DIXON, R. - ROZNAI, Y. From an Unconstitutional Constitutional Amendment to an Unconstitutional Constitution? Lessons from Honduras. In Global Constitutionalism, 2019, roč. 8, č. 1, s. 60 . 
V tomto smere ide o globálny trend, ktorý do rámca súdneho prieskumu národných súdnych inštancií priniesli externé právne pramene. Národné súdy využili pramene medzinárodnej sféry na posilnenie svojho národného statusu (rozsah právomocí) pri prieskume vnútroštátnych aktov. ${ }^{64}$

Externé pramene tak cez národné súdne inštancie môžu vytvárat' limity ústavodarného orgánu. ${ }^{65} \mathrm{~V}$ minulosti vel'mi kontroverzná, či dokonca možno až kacírska myšlienka je dnes pomerne široko akceptovaná. Pre to, aby to tak bolo, musia tieto limity ako relevantné, či dokonca základné uznat' samotné ústavné dokumenty. ${ }^{66}$ Suverénne štáty totiž nerešpektujú účinky medzinárodného práva z dôvodu akceptácie univerzalistickej koncepcie (t. j. monistickej nadradenosti medzinárodného práva ${ }^{67}$ ), ale preto, že sa tak sami rozhodnú. Vo svete neexistuje právny poriadok, ktorý by sa automaticky a za každých okolností podriad’oval medzinárodnému právu. Materiálny základ akceptácie takýchto účinkov má teda vnútroštátny, resp. ústavný pôvod. ${ }^{68}$

$\mathrm{V}$ tejto časti budú postupne analyzované tri základné externé limity, ktoré pre výkon ústavodarného orgánu môžu existovat'. Postupne sa tak bližšie rozoberú limity, ktoré svojou povahou vychádzajú z (I) prirodzeného práva, (II) medzinárodného práva a (III) supranacionálneho práva.

\section{Prirodzené právo}

Prirodzené právo od nepamäti vytvára limity výkonu akejkol’vek moci, a to nielen ustanovenej, ale aj moci originálnej. Už Jean Bodin, autor slávnej koncepcie štátnej suverenity, tvrdil, že moc suveréna nie je neobmedzená, ale že aj ,pozemský suverén je subjektom božích zákonov, zákonov prírody, ako aj d’alších l'udských pravidiel, ktoré platia pre všetkých l'udi'“. ${ }^{69}$ Hlavný architekt originálnej ústavodarnej moci Abbé Sieyès vo svojom legendárnom diele „Qu'est-ce que le Tiers état?“, v ktorom rozlíšil ustanovujúcu a ustanovenú moc, uvádza, že „národ existuje pred všetkým. Je základom všetkého. Jeho vôl'a je vždy zákonná. Ustanovená moc, na druhej strane, je neoddelitel’ná od predurčeného ústavného poriadku“ “ ${ }^{70}$ Avšak aj Sieyès a jeho teória neobmedzenej moci originálnej moci, ktorú následne rozšírili a prehĺbili (a občas aj zneužili) d’alší právni teoretici, mala limit. Roznai si

${ }^{64}$ LUSTIG, D. - WEILER, J., H., H. Judicial review in the contemporary world - Retrospective and prospective. In International Journal of Constitutional Law, 2018, roč. 16, č. 2, s. 325 - 329; BENVENISTI, E. Reclaiming Democracy: The Strategic Uses of Foreign and International Law by National Courts. In American Journal of International Law, 2008, roč. 102, s. 241 - 274.

${ }^{65}$ ALBERT, R. Constitutional Amendments. Making, Breaking and Changing Constitutions. New York : Oxford University Press, 2019, s. 221 - 222.

${ }^{66}$ ROZNAI, Y. Unconstitutional Constitutional Amendments. The Limits of Amendment Powers. Oxford: Oxford University Press, 2017, s. 72.

${ }^{67}$ BARANÍK, K. Ústava na hviezdnom nebi. Vzt'ah Ústavy Slovenskej republiky k medzinárodnému právu. Praha : Leges, 2020, s. $61-63$.

${ }^{68}$ Typickým príkladom je Švajčiarsko, ktoré ústavne deklaruje záujem dodržiavat' medzinárodné právo (čl. 2 ods. 4 a čl. 5 ods. 4) a súčasne pri úplnej, ale aj čiastočnej revízii ústavného textu proklamuje nevyhnutnost' dodržiavania medzinárodného práva (čl. 193 ods. 4 a čl. 194 ods. 2).

${ }^{69}$ ROZNAI, Y. Unonstitutional Constitutional Amendments. The Limits of Amendment Powers. Oxford University Press, 2017, s. 73.

${ }^{70}$ SIEYĖS, A. Qu'est-ce que le Tiers état? Paris : Éditions du Boucher, 2002, s. 53. 
všíma, že vyššie zmienený citát, v ktorom je moc národa definovaná ako ultimátna, zvyčajne neuvádza nasledujúcu, avšak vel'mi podstatnú vetu. ${ }^{71}$ Tá má zásadný význam a výrok o absolútnom postavení suverénneho národa zásadne modifikuje. Uvedený doslov znie „Pred a nad národom stojí už len prirodzené právo." ${ }^{\text {"72 }}$ Prirodzené právo tak bolo aj pre Sieyèsa limitom originálnej ústavodarnej moci každého národa. Aj samotný architekt doktríny neobmedzenej suverénnej moci l'udu teda uznával obmedzenie tejto ultimátnej, tým pádom však nie finálnej a absolútne neobmedzenej moci l'udu (= suveréna). Tento limit je externý, no podl'a uvedeného súčasne aj implicitný a inherentný. To smeruje k prítomnosti obmedzení výkonu ústavodarnej moci základnými predpokladmi existencie medzinárodného spoločenstva a základnými podmienkami slušnosti. ${ }^{73}$ Prirodzenoprávne normy, dovolávajúce sa l'udskosti a slušnosti, sú však, samozrejme, len t’ažko „uchopitel'né“ a pravdepodobne aj ked' by mali byt' aplikovatel'né vo všetkých štátoch, sú predovšetkým univerzálne nevynútitel'né. ${ }^{74}$ Napriek tomu prináša prirodzené práva ako limit národného suveréna nekončiacu diskusiu, ktorá sa dotýka podstaty a zmyslu existencie práva.

\section{Medzinárodné právo}

Textovým východiskom ústavného ukotvenia potenciálnych limitov ústavodarnej moci, ktoré vyplývajú z medzinárodného práva, je na Slovensku nepochybne čl. 1 ods. 2. Toto ustanovenie naznačuje príklon slovenského ústavného poriadku k monistickému vnímaniu vzt’ahu vnútroštátneho a medzinárodného práva. Slovenská republika sa ním zaväzuje uznávat' a dodržiavat' „všeobecné pravidlá medzinárodného práva, medzinárodné zmluvy, ktorými je viazaná, a svoje d’alšie medzinárodné záväzky“. Podl’a dôvodovej správy toto ustanovenie implicitne odkazuje na čl. 27 Viedenského dohovoru o zmluvnom práve, podl'a ktorého sa „strana nemôže dovolávat' ustanovení svojho vnútroštátneho práva ako dôvodu proti neplneniu zmluvy“. Vnútroštátna akceptácia tohto základného pravidla medzinárodného práva poskytuje argument na to, aby aj v prípade rozporu relevantného ustanovenia medzinárodnej zmluvy s vnútroštátnou normou akejkol'vek právnej sily, a teda (teoreticky) aj ústavnej povahy, napokon prevládol medzinárodný záväzok. ${ }^{75}$ Takáto konštrukcia implicitnej akceptácie čl. 27 Viedenského dohovoru v čl. 1 ods. 2 je však len teoretická, smerujúca k absolútnemu monizmu s primátom medzinárodného práva. ${ }^{76}$ Ako už bolo spomenuté, takéto chápanie ultimátnej sily medzi-

\footnotetext{
${ }^{71}$ ROZNAI, Y. The Boundaries of Constituent Authority. In Connecticut Law Review, forthcoming 2020, s. 8 .

72 «Avant elle et au-dessus d'elle il n’y a que le droit naturel.» SIEYÈS, A. Qu'est-ce que le Tiers état? Paris : Éditions du Boucher, 2002, s. 53.

${ }^{73} \mathrm{~K}$ diskusii o prirodzenoprávnom základe právneho poriadku a Ústavy USA pozri rozhodnutia Najvyššieho súdu Spojených štátov Calder v. Bull, 3 U.S. (3 Dall.) 386 (1798) a The Antelope 23 U.S. (10 Wheat.) 66 (1825).

${ }^{74}$ GARLICKI, L. - GARLICKA, Z. A. External Review of Constitutional Amendments? International Law as a Norm of Reference. In Israel Law Review, 2011, roč. 44, s. 355 - 357.

${ }^{75}$ BARANÍK, K. Ústava na hviezdnom nebi. Vzt'ah Ústavy Slovenskej republiky k medzinárodnému právu. Praha : Leges, 2020, s. 177.

${ }^{76}$ GRAGL, C. Legal Monism. Law, Philosophy and Politics. Oxford : Oxford University Press, 2018, s. $110-121$.
} 
národného práva doteraz žiaden štát neakceptoval. ${ }^{77}$ Ústavný súd dodnes uznal prednost' kvalifikovaných medzinárodných záväzkov „len“ pred zákonmi, nie pred ústavou. ${ }^{78}$

Ak však akceptujeme tézu, podl’a ktorej má suverenita štátu limity, ktoré sú evidentné s ohl'adom na existenciu medzinárodného spoločenstva, resp. suverenít iných štátov, potom môžeme uvažovat' o externých ústavných limitoch. ${ }^{79}$ Jedná sa teda o praktické konzekvencie existencie štátu v medzinárodnom spoločenstve. Podstata týchto limitov vyviera z úplne iných predpokladov, ako to bolo v prípade interných, rýdzo ústavných limitov.

$\mathrm{Na}$ tieto predpoklady reaguje text preambuly. Zakotvenie „,My národ slovenský, ... vychádzajúc z prirodzeného práva národov na sebaurčenie, ... v záujme trvalej mierovej spolupráce s ostatnými demokratickými štátmi, ... “ naznačuje úmysel dodržiavat' základné pravidlá medzinárodného spoločenstva, ktorého je Slovenská republika integrálnou súčast'ou. Nejde teda len o akúsi slobodnú vol'bu suveréna, ale v podstate o conditio sine qua non existencie štátu $\mathrm{v}$ medzinárodnom priestore. Ak chce byt' suverénny štát skutočne suverénnym, potom ho tak musia akceptovat' aj ostatné štáty. Dodržiavanie vlastných medzinárodných záväzkov, medzinárodnej obyčaje, či ius cogens sú základnými predpokladmi pre reálnu, nie len faktickú suverenitu konkrétneho štátneho útvaru.

\section{Ludskoprávny štandard (explicitný limit)}

Vel'ký segment medzinárodných záväzkov Slovenskej republiky, ktoré sú ústavnoprávne relevantné, majú l’udskoprávnu povahu. V zmysle čl. 7 ods. 5, čl. 154c ods. 1 a čl. 153 môžu takéto ustanovenia za určitých podmienok priamo zakladat' vnútroštátne práva a povinnosti fyzických a právnických osôb ${ }^{80}$. Dodržiavanie a rešpektovanie týchto zakotvení je ústavne relevantné, a to bez ohl'adu na to, že ich pôvod sa nachádza mimo slovenského právneho poriadku. Aplikácia l’udskoprávnych medzinárodných zakotvení je prirodzene prepojitel'ná s čl. 12 ods. $1 .{ }^{81}$ Ako už bolo uvedené, toto ustanovenie explicitne konštatuje aj nezrušitel’nost' základných práv. ${ }^{82}$ L'udskoprávna ochrana poskytovaná medzinárodnými zmluvami sa do rámca čl. 12 ods. 1 nepochybne zmestí. To potvrdil aj

${ }^{77}$ Porovnaj s ROZNAI, Y. Unonstitutional Constitutional Amendments. The Limits of Amendment Powers. Oxford : Oxford University Press, 2017, s. 71 - 72 a ROZNAI, Y. The Theory and Practice of "SupraConstitutional" Limits on Constitutional Amendments. In International and Comparative Law Quarterly, 2013, roč. 62 , č. 3 , s. 577 - 580. Vyskytli sa však ojedinelé prípady akceptácie prednosti medzinárodného práva pred ústavou. Príkladom je Honduras, kde najvyšší súd deklaroval, že disponuje právomocou zrušit’ časti ústavného poriadku z dôvodu ich nekompatibility s medzinárodnými princípmi. Bližšie LANDAU, D. E. - DIXON, R. - ROZNAI, Y. From an unconstitutional constitutional amendment to an unconstitutional constitution? Lessons from Honduras. In Global Constitutionalism, 2019, roč. 8, č. 1, s. 42, 60 - 66.

${ }^{78} \mathrm{~K}$ tomu uznesenie sp. zn. PL. ÚS 44/03.

${ }^{79}$ BARANÍK, K. Suverenita Slovenskej republiky v procese európskej integrácie. In Acta Iuridica Olomucensia. 2019, roč. 14, č. 1, s. 59.

${ }^{80} \mathrm{Ku}$ kategóriám medzinárodných zmlúv aplikovaných na základe ústavného statusu pozri BARANÍK, K. Ústava na hviezdnom nebi. Vzt'ah Ústavy Slovenskej republiky k medzinárodnému právu. Praha : Leges, 2020, s. $193-201$.

${ }^{81}$ Ludskoprávny aspekt medzinárodných zmlúv zdôrazňuje Ústava SR aj v čl. 13 ods. 1 písm. b), čl. 127 ods. 1 a 2, čl. 130 ods. 1 písm. g).

${ }^{82}$ PL. ÚS 24/2014. 
Ústavný súd, ked' v PL. ÚS 24/2014 prepojil nezmenitel'nost' ústavných článkov garantujúcich základné práva s ich ,štandardom vyplývajúcim z medzinárodnoprávnej úpravy i úpravy vo vnútroštátnom právnom systéme“. Ústavný súd teda štandard medzinárodnej a ústavnej ochrany „zlieva“ do konceptu základných práv a slobôd, ktorý má svoje východisko práve v čl. 12 ods. 1 . S ohl’adom na judikatúru nadnárodných súdnych inštancií, predovšetkým Európskeho súdu pre l'udské práva, je tento proaktívny prístup Ústavného súdu k ochrane l'udských práv nepochybne správny. ${ }^{83}$

Na skutočnost' relevancie l'udskoprávneho limitu činnosti ústavodarného orgánu poukazujú aj Káčer s Neumannom ${ }^{84}$, ktorí presvedčivo argumentujú, že výkon originálnej (ústavodarnej) moci mal v novodobej histórii našej republiky bližšie k Listine základných práv a slobôd ako k Ústave SR. ${ }^{85}$ Navyše, neznižovanie l'udskoprávnych štandardov, a to aj tých, ktoré vyplývajú z externých záväzkov, nie je v európskom priestore vôbec žiadnou ústavnoprávnou „exotikou“ porovnatel'nou s tým, čo bolo vyslovené pri konštruovaní implicitného materiálneho jadra ústavy v PL. ÚS 21/2014. Jednotlivec sa v globalizovanom prostredí stal hybnou silou rozvoja národného právneho poriadku, ako aj medzinárodného práva ${ }^{86}$ Preto možno l'udskoprávny štandard zakotvený na medzinárodnej úrovni a akceptovaný Slovenskou republikou otvorene označit' nielen za implicitný, ale predovšetkým explicitný limit výkonu ústavodarnej moci. Obdobné závery nemali doteraz problém uznat tie ústavné poriadky, ktorých podstata vychádza z koncepcie l'udskej dôstojnosti. Slovenská republika by teda nemala vytvárat' vnútroštátne normy, a to ani ústavného charakteru, ktoré by odporovali jej l'udskoprávnym medzinárodným záväzkom.

\section{Ďalšie medzinárodné záväzky (implicitné limity)}

Pri možných porušeniach medzinárodných záväzkov nasledujú niektoré štáty doktrínu, podl’a ktorej sa pri medzinárodnom záväzku nepripúšt’a implicitná derogácia iným, a to ani ústavným, vnútroštátnym právnym predpisom. ${ }^{87}$ Toto pravidlo nadväzuje na zásadu, podl'a ktorej nemá parlament v princípe úmysel porušit' medzinárodné záväzky štátu. Činnost' tohto orgánu je totiž pričítatel'ná štátu, z čoho vyplýva, že legislatívnou aktivitou môže dôjst' $\mathrm{k}$ porušeniu medzinárodného záväzku a následne k vzniku medzinárodnej zodpovednosti. Doktrína zákazu implicitnej derogácie zabezpečuje, že nemôže dôjst' k neúmyselnému porušeniu medzinárodného záväzku. Na druhej strane však nevylučuje, aby parlament napokon nemohol porušit' medzinárodné záväzky štátu. Vôl'a po-

\footnotetext{
${ }^{83} \mathrm{~K}$ tomu bližšie L'ALÍK, T. Vplyv judikatúry Európskeho súdu pre l’udské práva na rozvoj l’udských práv v Slovenskej republike. In Justičná revue, 2009, roč. 61, č. 12, s. $1305-1324$.

${ }^{84}$ KÁČER, M. - NEUMANN, J. Materiálne jadro v slovenskom ústavnom práve. Doktrinálny disent proti zrušeniu sudcovských previerok. Praha : Leges, 2019, s. 132 - 139.

${ }^{85}$ Ibid., s. 135.

${ }^{86}$ Konštitucionalizmus 3.0 sa na rozdiel od Konštitucionalizmu 2.0 stal nadnárodným projektom (SOMEK, A. The Cosmopolitan Constitution. Oxford : Oxford University Press, 2014, s. 157).

${ }^{87} \mathrm{~K}$ tomu pozri bližšie GARDBAUM, S. The Commonwealth Model of Constitutionalism. In American Journal of Comparative Law. 2001, roč. 49, č. 4, s. 707 - 760.
} 
rušit’ medzinárodné záväzky štátu však musí byt' vyjadrená explicitne. ${ }^{88}$ Ide o o akési jemné (soft) obmedzenie ústavodarnej právomoci. Tá sa síce nelimituje, no na jej použitie je nevyhnutná explicitná deklarácia, t. j. úmysel, smerujúci k porušeniu medzinárodného záväzku ústavodarným orgánom.

Vzhl'adom na ústavodarnú prax na Slovensku sa možno nazdávat', že potreba zmienenej explicitnej deklarácie by v mnohých prípadoch mohla slúžit' ako dostatočne silná zábrana výkonu ústavodarnej právomoci proti medzinárodným záväzkom. V takomto prípade by sa teda uplatnila vnútroštátna suverenita, ktorá by umožnila vzopriet' sa medzinárodným povinnostiam Slovenskej republiky. Táto deklarácia by však v konečnom dôsledku spôsobila explicitné porušenie čl. 1 ods. 2. Súčasne by takýto akt pravdepodobne podnietil vznik medzinárodnej zodpovednosti, ktorú nesie vždy štát ako subjekt medzinárodného práva. ${ }^{89}$

Ako d'alšie je vhodné uviest' implicitné obmedzenia ústavodarnej právomoci vyplývajúce Slovenskej republike z členstva v medzinárodných organizáciách. Zakladajúce listiny (medzinárodné zmluvy) stanovujú základné predpoklady pre členstvo v týchto organizáciách. ${ }^{90} \mathrm{~V}$ tomto smere možno spomenút' členstvo Slovenskej republiky v OSN či v Rade Európy. Ak by napríklad Slovenská republika zaviedla trest smrti ${ }^{91}$, takmer s istotou by to znamenalo jej vylúčenie z Rady Európy ${ }^{92}$. V tomto smere teda ide o limity, ktoré vyplývajú z nadnárodnej príslušnosti Slovenskej republiky. Inými slovami, ak by ústavodarný orgán uplatnil ústavodarnú právomoc, ktorá by nebola konformná s požiadavkami na členstvo v príslušných medzinárodných organizáciách, znamenalo by to re-konfiguráciu postavenia, resp. až vylúčenie nášho štátu z medzinárodného spoločenstva.

Ďalšou, vel'mi súvisiacou skutočnost'ou, je potreba rešpektovat' základné pravidlá existencie štátu v medzinárodnom spoločenstve. Ak by napr. národná rada ústavným zákonom rozhodla o iniciácii útočnej vojny proti jednému zo svojich susedov, teoreticky by to bolo možné. Prakticky by však takýto „prejav suverenity“ znamenal porušenie pravidla ius cogens a pravdepodobne aj urýchlené zasadnutie Bezpečnostnej rady OSN. Nasledujúci sled udalostí by napokon mohol vyústit' do aktívnej reakcie medzinárodného spoločenstva a dokonca skončit' aj stratou suverenity Slovenskej republiky. Práve preto sa možno nazdávat', že slovenský ústavodarný orgán je implicitne limitovaný základnými zásadami medzinárodného práva.

Na podporu argumentácie v prospech medzinárodných limitov ústavodarnej moci, ktoré priamo podporuje text ústavy, je potrebné spomenút' aj čl. 133. ${ }^{93}$ Ten umožňuje obnovit'

${ }^{88}$ BARANÍK, K. Ústava na hviezdnom nebi. Vzt'ah Ústavy Slovenskej republiky k medzinárodnému právu. Praha : Leges, 2020, s. 100.

${ }^{89}$ Ibid., s. 178.

${ }^{90}$ LANDAU, D. Democratic Erosion and Constituion-Making Moments. In UC Irvine Journal of International, Transnational and Comparative Law, 2017, roč. 2, s. 100.

${ }^{91}$ GARLICKI, L. - GARLICKA, Z. A. External Review of Constitutional Amendments? International Law as a Norm of Reference. In Israel Law Review, 2011, roč. 44, s. 366-367.

${ }_{92} \mathrm{~V}$ zmysle protokolu č. $6 \mathrm{k}$ Dohovoru o ochrane l’udských práv a základných slobôd je trest smrti zakázaný. Vylučuje sa pritom akákol'vek derogácia tejto povinnosti.

${ }_{93}$ Pre detailnejší rozbor, ako aj d’alšie alternatívy potenciálnych intersystémových konfliktov pozri BARANÍK, K. Rozhodnutia medzinárodných orgánov a obnova konania pred Ústavným súdom SR. In BARANÍK, K. (ed.). Výzvy a perspektivy vývoja ústavného práva Slovenskej republiky v procese európskej 
konanie pred ústavným súdom v prípade, ak by sa rozhodnutie Ústavného súdu dostalo do rozporu s rozhodnutím medzinárodného orgánu. Toto ustanovenia tak umožňuje „,pozmenit“" výsledok rozhodovacej činnosti ústavného súdu (t. j. ústavnú úroveň slovenského právneho poriadku) na základe externého sekundárneho právneho aktu. Nedá sa predpokladat', že by rozhodnutie ústavodarného orgánu malo mat' ambíciu ,rušit““ účinky rozhodnutí medzinárodných súdnych orgánov prostredníctvom prijímania či už samostatne stojacich ústavných zákonov alebo ústavných noviel. S ohl'adom na pro-medzinárodný vývoj slovenského ústavného poriadku by však takáto ústavodarná činnost' mala byt' implicitne vylúčená.

\section{Supranacionálne právo}

Posledným limitom ústavodarnej moci, s ktorým však ústava (v čl. 7 ods. 2) explicitne neráta, je nadradený, resp. prednostný účinok práva Európskej únie. Ústavná zmena, ktorá by sa priečila právu EÚ, by bola $\mathrm{v}$ zmysle rozhodovacej činnosti Súdneho dvora EÚ neúčinná, resp. by nebola aplikovatel’ná. V zmysle konštantnej judikatúry Súdneho dvora EÚ, počnúc rozhodnutím vo veci Costa $(1964)^{94}$, sa v právnych poriadkoch členských štátov stalo prednostné pôsobenie práva EÚ nepopieratel'ným kánonom jeho aplikácie. ${ }^{95} \mathrm{~V}$ tomto smere nie je podstatné, či právo EÚ zakazuje určitú reguláciu v primárnom alebo sekundárnom práve. Vnútroštátna kategorizácia prameňov práva EÚ nie je s ohl'adom na ich vnútroštátne účinky relevantná.

Národná rada tak síce môže prijat’ ústavný zákon, ktorý by odporoval právu EÚ, avšak takáto ústavná úprava by bola v časti, ktorá by odporovala právu EÚ, neúčinná, resp. neaplikovatel’ná. Z toho vyplýva, že pristúpením do Európskej únie členské štáty stratili možnost' vnútroštátne podmienit' účinky práva EÚ. ${ }^{96}$ Musia totiž zabezpečit' jeho efektívnu aplikáciu (effet utile). ${ }^{97} \mathrm{~V}$ tomto smere je právo EÚ nekompromisné. ${ }^{98}$

Podl'a tradičnej teoretickej premisy supranacionálne inštitúcie operujú v odlišných právnych systémoch ako národné orgány. Vnútroštátny právny akt doteraz nemohol byt’

integrácie a globalizácie. Bratislava : Univerzita Komenského v Bratislave, Právnická fakulta, 2017, s. 106 122. Porovnaj s MAZÁK, J. Obnova konania pred Ústavným súdom SR: Prvé skúsenosti, pochybnosti a jeden námet. In Bulletin slovenskej advokácie, 2007, roč. 23, č. 11, s. 24 - 29; BALOG, B. - TRELLOVÁ, L. Obnova konania pred ústavným súdom ako prostriedok ochrany ústavnosti. In OROSZ, L. - GRABOWSAKA, S. - MAJERČÁK, T. (eds.). Tretie funkčné obdobie ústavného súdu Slovenskej republiky. VII. ústavné dni. Košice : Univerzita Pavla Jozefa Šafárika, 2019, s. 125 - 140.

${ }^{94}$ Rozhodnutie z 3. júna 1964, Costa v E.N.E.L., 6/64 [1963], EU:C:1964:66.

${ }^{95} \mathrm{~K}$ tomu pozri WEILER, J. The Transformation of Europe. In The Yale Law Journal. 1991, č. 8, s. 2403 $-2483$.

${ }^{96}$ Pre úplnost' možno dodat', že ústavné poriadky jednotlivých členských štátov, a to najmä na čele s najvyššími súdnymi orgánmi, prejavujú určitú formu rezistencie vo vzt’ahu k právu EÚ. K tomu pozri napr. BARANÍK, K. Kontrolná činnost' ústavného súdnictva vo vzt’ahu k členstvu v Európskej únii - realita alebo fikcia? In Bratislavské právnické fórum, 2018, s. 14 - 16.

${ }^{97}$ Ide pritom o snahu o maximálny, neoslabený účinok práva EÚ vo všetkých členských štátoch EÚ. K tomu bližšie napr. TOMÁŠEK, M. - TÝČ, V. a kol. Právo Evropské unie. 2. aktualizované vydání. Praha : Leges, 2017, s. 105. Pre špecifiká konceptu „,effet utile“ pozri TICHÝ, L. - KOCÍ, M. Effet utile v právu EU (kritická skica). In Právník, 2015, č. 2, s. 164 - 181.

${ }^{98}$ BARANÍK, K. Ústava na hviezdnom nebi. Vzt'ah Ústavy Slovenskej republiky k medzinárodnému právu. Praha : Leges, 2020, s. 263. 
rušený súdnou inštanciou iného právneho systému. ${ }^{99}$ To však dnes už neplatí absolútne. Súdny dvor EÚ začal túto teoretickú koncepciu „prekopávat““. ${ }^{100}$ Ide o d'alšiu verziu implikovaných právomocí, na ktorých základe preniká právo EÚ čoraz hlbšie do ústavných systémov členských štátov, čím ich implicitne limituje.

\section{Záver: Balans demokracie a konštitucionalizmu pri výkone ústavodarnej moci}

Predošlý text analyzoval limity, ktoré slovenský ústavný poriadok explicitne alebo implicitne stanovuje výkonu ústavodarnej právomoci. Ako už bolo uvedené, výkon pôvodnej ústavodarnej moci je tradične považovaný za neobmedzitel'ný. Na druhej strane, národná rada, hoc konajúca ako ústavodarný orgán, je stále „len“ orgánom ustanoveným, ktorý aj pri výkone ústavodarnej moci musí rešpektovat' ústavou stanovené pravidlá, procesy a limity.

V príspevku bolo demonštrované, že aj ked' sa pri úvahách o realizácii ústavodarnej právomoci v našich podmienkach zväčša skízne len do roviny čistokrvnej politickej matematiky, limity jej výkonu existujú. A to explicitné predpoklady, ako aj implicitné podmienky jej realizácie. Základom implicitných limitov je logika existencie ústavy ako zakladajúceho dokumentu štátu (interné limity), ako aj toho, že Slovenská republika neexistuje vo vákuu či v režime absolútnej suverenity, ale v medzinárodnom spoločenstve, kde je každý subjekt povinný rešpektovat' určité pravidlá (externé limity). Suverenita žiadneho štátu nemôže byt' neohraničená. Je obmedzená minimálne výkonom suverenít iných štátov. Popretím tejto logiky, resp. nerešpektovaním medzinárodných záväzkov či základných pravidiel fungovania medzinárodného spoločenstva, by Slovenská republika nemohla $\mathrm{v}$ tomto medzinárodnom spoločenstve existovat'.

Miera limitov výkonu ústavodarnej moci je dôsledkom balansu konštitucionalizmu a demokracie. Ani jeden z týchto komponentov by nemal nadobudnút' absolútnu dominanciu. Výkon ústavodarnej právomoci nesmie byt' čistokrvným politickým kalkulom a nevyhnutne musí byt’ limitovaný základnými princípmi konštitucionalizmu. Na druhej strane by však ani samotný konštitucionalizmus nemal „diktovat““ neprekonatel’né prekážky výkonu právomoci ústavodarného orgánu. Z tohto pohl'adu je koncept nezmenitel'ných ústavných článkov nesprávnym prístupom. Tým, že absolútne obmedzuje výkon ústavodarnej moci v určitých segmentoch, ,prikováva“ d’alšie generácie k preferenciám tej prvej. $Z$ rovnakého dôvodu je nevhodným inštrumentom na dosiahnutie ústavnej rovnováhy aj implicitná nezmenitel'nost'. V nej totiž záväzný interpretátor ústavného textu vyjadruje vlastnú (trvalú) preferenciu ústavnej nezmenitel’nosti. Pomyselne tým preberá

\footnotetext{
${ }^{99} \mathrm{~V}$ tomto smere existuje zásadným rozdiel medzi chápaním nadradenosti a prednostným účinkom práva EÚ v právnych poriadkov členských štátov. K vysvetleniu účinkov práva EÚ pozri AVBELJ, M. Supremacy or Primacy of EU Law - (Why) Does it Matter. In European Law Journal, roč. 17, č. 6, s. 745 - 754.

${ }^{100}$ Rozsudok z 26. februára 2019, Ilmārs Rimšēvičs a Európska centrálna banka (ECB) proti Lotyšskej republike, spojené veci C-202/18 a C-238/18. K tomu bližšie MAZÁK, J. Súdny dvor EÚ zrušil vnútroštátny právny akt: rodí sa nová doktrína alebo výnimka potvrdzuje pravidlo? In KYSELOVSKÁ, T. - SEHNÁLEK, D. - ROZEHNALOVÁ, N. (eds.). In varietate concordia: soubor vědeckých statí k poctě prof. Vladimíra Týče. 1. Brno : Masarykova univerzita, 2019, s. 208.
} 
rolu pôvodného ústavodarcu, a to bez náležitej legitimity. Deklarácia implicitnej nezmenitel’nosti vždy predstavuje konanie ultra vires. $Z$ ultimátneho interpretátora by sa nemal stat' konečný posudzovatel' akejkol’vek budúcej zmeny ústavného textu. Ústavný súd má ústavný text interpretovat', nie ho tvorit' a bránit' jeho d’alšej zmene.

Nastavenie slovenskej verzie ústavodarného procesu, ktoré napokon vyústilo do deklarácie nezmenitel'ného implicitného materiálneho jadra v roku 2019, vykonal originálny ústavodarca ešte v roku 1992. Ten pri konštruovaní mechanizmu ústavných zmien, t. j. pri výkone delegovanej ústavodarnej moci, úplne odignoroval del'bu moci. Túto kritickú právomoc $\mathrm{v}$ úplnosti zveril do rúk jedinej komory rýdzo politického orgánu. Tým na pomyselný piedestál výkonu ústavodarnej právomoci „posadil“ väčšinové rozhodovanie, t. j. demokraciu. „Dokonale“ tým poprel potrebu inštitucionálneho balansu, ktorý je symbolom del'by moci, čiže podstatou konštitucionalizmu. V nasledujúcich, už takmer troch dekádach ústavného vývoja, sa absencia vyvažovania v „politickej aréne“, žial', dlhodobo akceptovala. Ak bol pôvodný ústavodarca v tomto smere pomyselným ,prvotným hriešnikom“, všetci nasledujúci reprezentanti ústavodarného orgánu toto „ústavné hrešenie“ nasledovali. Ústavodarný proces sa politicky zneužíva. Počas dlhých rokov neprebehla komplexná celospoločenská, odborná či akákol'vek iná diskusia o vytvorení vnútorných poistiek, t. j. explicitných limitoch výkonu ústavodarnej moci. ${ }^{101}$ Proces prijímania ústavných zmien je dodnes až smiešne jednoduchý ${ }^{102}$, neuplatňuje sa v ňom princíp del'by moci, čo napomáha $\mathrm{k}$ jeho politickému zneužívaniu. Pritom ide o absolútne klúčovú procedúru celého ústavného poriadku. Takéto nastavenie vyhovuje politikom, ktorí ako jediní môžu na veci niečo zmenit'. Implicitný limit výkonu ústavodarnej moci, ktorý deklaroval Ústavný súd, bol očividným prekročením jeho právomoci. Na druhej strane však táto plenárna deklarácia ultimátneho obmedzenia získala legitimitu práve cez neustále zneužívanie ústavodarnej právomoci.

Aké sú teda možnosti ústavodarného orgánu, aby už zásahy ústavného súdnictva do výkonu ústavodarnej právomoci neboli potrebné, resp. aby boli vnímané ako nelegitímne? V tomto smere by pri výkone ústavodarnej moci bolo vhodné vytvorit’ už spomínaný balans konštitucionalizmu a demokracie. Skutočná aplikácia princípu del'by moci by nepochybne oslabila potrebu ultra vires zásahov ústavného súdnictva do výkonu tejto právomoci. Neobmedzená politika a formulácia materiálneho jadra sa nachádzajú na pomyselných koncových hranách demokracie (neobmedzená moc politiky) a konštitucionalizmu (explicitné, či implicitné deklarácie nezmenitel’nosti). Tieto riešenia s ambíciou finality nie sú vhodné a neprimerane polarizujú celkový vývoj ústavného práva.

${ }^{101}$ Akademici často individuálne apelovali za zmenu ústavodarného procesu, avšak nedokázali vytvorit’ konzistentný tlak, ktorý by ju aj vynútili. Pre návrhy pozri napr. PROCHÁZKA, R. L’ud a sudcovia v konštitučnej demokracii. Plzeň : Aleš Čeněk, 2011, s. 121 - 127.

${ }^{102}$ Lalík, citujúc výskum Tsebelisa (Tsebelis, 'Constitutional Rigidity Matters: A Veto Players Approach' (Working Paper 2018) 〈https://sites.lsa.umich.edu/tsebelis/working-papers/ 〉), poukazuje na to, že len Jamajka, Nový Zéland, Thajsko, Uruguaj a India majú flexibilnejšie ústavy ako Slovenská republika (LALÍK, T. The Slovak Constitutional Court on Unconstitutional Amendment (PL. ÚS 21/2014) In European Constitutional Law Review, 2020, roč. 16, č. 2, s. 336). Na základe uvedeného je slovenský ústavodarný proces najflexibilnejším v Európe (!). 
Vhodnejšie ako zakotvovat' nezmenitel'né články ústavy či ponechávat' plný priechod politike, ktorá skôr či neskôr zvedie ústavodarný orgán k politickému zneužitiu ústavodarného procesu a následne vyvolá potrebu deklarácie implicitných mantinelov tejto právomoci, je zvýšit' mieru procesnej rigidity ústavodarného procesu. Tá je dosiahnutel'ná práve rozptýlením ústavodarnej právomoci medzi viacero inštitúcií. Prípadne je do procesu ústavných zmien potrebné zapojit' (priamo alebo nepriamo) samotného suveréna. Taktiež by v tomto smere bolo vhodné stanovit' odlišné procedúry zmeny pre jednotlivé časti ústavy. To znamená odstupňovat' ich podl'a dôležitosti bez toho, aby niektoré z nich boli deklarované za ,nezmenitel'né“. ${ }^{103}$ Všetky zakotvenia v ústave by mali byt' novelizovatel'né riadnymi demokratickými procesmi. Neznamená to však, že všetko $\mathrm{v}$ ústave musí byt' zmenitel'né rovnakým, univerzálnym procesom. Odstupňovanie ústavnej rigidity tak môže priniest’ potrebnú ochranu pre kl'účové ústavné články.

História konštitucionalizmu je dejinami limitovaného výkonu moci. Súčasne je konštitucionalizmus charakterizovaný potrebou vzájomnej spolupráce a vyvažovaním právomoci tak, aby ani jedna $\mathrm{z}$ inštitúcií výkonu štátnej moci nenadobudla dominantné postavenie. ${ }^{104}$ Konanie Ústavného súdu ultra vires či zneužívanie právomoci ústavodarným orgánom sú dôsledkami nesprávne nastavenej rovnováhy pri výkone ústavodarnej moci. Tá musí mat' limity, ktorých strážcami musia byt' iné, najlepšie viaceré inštitúcie. Prípadne môže byt' do kontrolného procesu zapojený aj samotný suverén. Výkon tejto právomoci nesmie byt' ponechaný jedine na (svoj)vôl'u parlamentu. Ináč sme mu my všetci postavení na milost'. Implicitné obmedzenia výkonu moci sú potrebné len vtedy, ked'sa delegované právomoci nielen prekračujú, ale najmä politicky zneužívajú.

Zvýšenie rigidity niektorých častí ústavy, nie však ich konzervovanie na „večné veky“, nesmie slúžit' ako neprekonatel'ná prekážka dobre premyslenej a vhodnej ústavnej zmeny. Zvýšená ochrana a potreba inštitucionálnej spolupráce má zabránit’ neartikulovanému, nárazovému, často hysterickému a nedostatočne premyslenému politickému obchodovaniu, ktoré vystavuje riziku dlhodobé kryštalizovanie kl’účových ústavných hodnôt. Predíde sa tým potrebe „hasenia“ ústavne nehodných politických „trafík“ názorom trinástich nevolených sudcov a súčasne aj prípadným medzinárodným porušeniam, ktoré by mohli uvedené neuvážené vnútroštátne politické dohody Slovenskú republiku medzinárodne poškodit’.

\section{Literatúra}

ALBERT, R. Constitutional Amendments. Making, Breaking and Changing Constitutions. New York: Oxford University Press, 2019

ALBERT, R. Constitutional Handcuffs. In: Arizona State Law Journal, 2010, roč. 42, s. 663 - 715

ALBERT, R: Four Unconstitutional Constitutions and their Democratic Foundations. In: Cornell International Law Journal, 2017, roč. 50, s. $169-198$

ALBERT, R. The Difficulty of Constitutional Amendment in Canada. In: Alberta Law Review, 2015, roč. 53, s. $85-114$

${ }^{103}$ Albert pritom hovorí o ústavnom simulátore. ALBERT, R. Constitutional Handcuffs. In Arizona State Law Journal, 2010, roč. 42, s. $698-714$.

${ }^{104}$ K tomu HAMILTON, A. - MADISON, J. - JAY, J. Listy federalistov. Bratislava : Kalligram, 2002, s. 401 -407 (List č. 51). 
ALBERT, R. The Structure of Constitutional Amendment Rules. In: Wake Forest Law Review, 2014, roč. 49, S. $913-975$

AVBELJ, M. Supremacy or Primacy of EU Law - (Why) Does it Matter. In: European Law Journal, roč. 17, č. 6, s. $744-763$

BALOG, B. Materiálne jadro Ústavy Slovenskej republiky. 1. vydanie. Žilina : Eurokódex, 2014.

BARAK, A. Sudca v demokracii. Bratislava: Kalligram, 2016

BARANÍK, K. Ústava na hviezdnom nebi. Vzt’ah Ústavy Slovenskej republiky k medzinárodnému právu. Praha: Leges, 2020

BARANÍK, K. Ústavodarná moc a politika. In: VEČEŘA, M., HAPLA, M. (eds.). Weyrovy dny právní teorie. Brno : Masarykova univerzita, 2017, s. $31-55$

BENVENISTI, E. Reclaiming Democracy: The Strategic Uses of Foreign and International Law by National Courts. In American Journal of International Law, 2008, roč. 102, s. 241 - 274

DAILliER, P., FORTEAU, M., PELLET, A. Droit international public. $8^{e}$ édition. L.G.D.J., 2009.

DRGONEC, J. Ústava Slovenskej republiky. Teória a prax. 2. prepracované a doplnené vydanie. Bratislava : C. H. Beck, 2019

DRGONEC, J. Základné práva a slobody a vyvodená pôsobnost' Ústavného súdu SR. In: OROSZ, L., MAJERČÁK, T. a kol. Ochrana l’udských práv a základných slobôd ústavnými súdmi a medzinárodnými súdnymi orgánmi - III. ústavné dni. Košice 2014. s. 177 - 193

GARLICKI, L, GARLICKA, Z., A. External Review of Constitutional Amendments? International Law as a Norm of Reference. In Israel Law Review, 2011, roč. 44, s. 343 - 368

GIBA, M. a kol. Ústavné právo. Bratislava : Wolters Kluwer, 2019

GIOVANNONI, F. Amendment Rules in Constitutions. In Public Choice, 2003, roč. 115, č. 1 - 2, s. 37 - 61

GÖZLER, K. Pouvoir Constituant. Bursa [Turquie], Editions Ekin Kitabevi, 1999. Dostupné online na http:// www.anayasa.gen.tr/pconstituant.htm\#_ftn1

GRAGL, C. Legal Monism. Law, Philosophy and Politics. Oxford : Oxford University Press, 2018

HAMILTON, A., MADISON, J., JAY, J. Listy federalistov. Bratislava : Kalligram, 2002

HART, H., L., A. Pojem práva. Praha : Prostor, 2004

HOLLÄNDER, P. Filosofie práva. 2. rozšírené vydání. Plzeň : Aleš Čeněk, 2012

HOLLÄNDER, P. Základy všeobecné státovědy. 3. vydání. Plzeň : Aleš Čeněk, 2012

KÁČER, M., NEUMANN, J. Materiálne jadro v slovenskom ústavnom práve. Doktrinálny disent proti zrušeniu sudcovských previerok. Praha : Leges, 2019

KELSEN, H. Pure Theory of Law. $5^{\text {th }}$ print. Berkeley : University of California Press, 2008

KYSELA, J. Ústava mezi právem a politikou. Úvod do ústavní teorie. Praha : Leges, 2014

LANDAU, D. Democratic Erosion and Constituion-Making Moments. In UC Irvine Journal of International, Transnational and Comparative Law, 2017, roč. 2, s. 87 - 112

LANDAU, D. E., DIXON, R., ROZNAI, Y. From an Unconstitutional Constitutional Amendment to an Unconstitutional Constitution? Lessons from Honduras. In Global Constitutionalism, 2019, roč. 8, č. 1, s. 40 - 70

LUSTIG, D., WEILER, J. H. H. Judicial review in the contemporary world - Retrospective and prospective. In International Journal of Constitutional Law, 2018, roč. 16, č. 2, s. 315 - 372

LUTZ, D., S. Principles of Constitutional Design. Cambridge: Cambridge University Press, 2006

L'ALÍK, T. The Slovak Constitutional Court on Unconstitutional Amendment (PL. ÚS 21/2014) In European Constitutional Law Review, 2020, roč. 16, č. 2, s. 328 - 343

L'ALÍK, T. Ústavodarná moc - včera, dnes a zajtra. In: Právník, 2016, č. 6, s. 509 - 525

L'ALÍK, T. Ústavný súd a parlament v konštitučnej demokracii. Bratislava : Wolters Kluwer, 2015

LALÍK, T. Vplyv judikatúry Európskeho súdu pre l'udské práva na rozvoj l'udských práv v Slovenskej republike. In Justičná revue. 2009, roč. 61, č. 12, s. 1305 - 1324

MALENOVSKÝ, J. Mezinárodní právo veřejné (obecná část) a poměr k jiným právním systémům. 6., upravené a doplněné vydání. Brno-Plzeň : Aleš Čeněk, 2014

MAZÁK, J. Súdny dvor EÚ zrušil vnútroštátny právny akt: rodí sa nová doktrína alebo výnimka potvrdzuje pravidlo? In KYSELOVSKÁ, T., SEHNÁLEK, D. ROZEHNALOVÁ, N. (eds.). In varietate concordia: soubor vědeckých statí k poctě prof. Vladimíra Týče. 1. Brno : Masarykova univerzita, 2019, s. $197-210$ 
PROCHÁZKA, R. L’ud a sudcovia v konštitučnej demokracii. Plzeň : Aleš Čeněk, 2011

ROSENFELD, M., SÁJO, A. (eds.). The Oxford Handbook of Comparative Constitutional Law. Oxford : Oxford University Press, 2012

ROZNAI, Y. The Boundaries of Constituent Authority. In Connecticut Law Review, forthcoming 2020, s. 1 - 23 ROZNAI, Y. The Theory and Practice of "Supra-Constitutional" Limits on Constitutional Amendments. In International and Comparative Law Quarterly, 2013, roč. 62, č. 3, s. 557 - 597

ROZNAI, Y. Unconstitutional Constitutional Amendments. The Limits of Amendment Powers. Oxford : Oxford University Press, 2019

ROZNAI, Y. Unconstitutional Constitutional Change by Courts, In New England Law Review, 2018, roč. 51, s. $555-577$

SCHMITT, C. Constitutional Theory, Durham a Londýn : Duke University Press, 2008

SIEYÈS, E. Qu'est-ce que le Tiers état? Paris : Éditions du Boucher, 2002

SOMEK, A. The Cosmopolitan Constitution. Oxford : Oxford University Press, 2014

TOMÁŠEK, M., TÝČ, V. a kol. Právo Evropské unie. 2. aktualizované vydání. Praha : Leges, 2017

\section{Príloha - Limity výkonu ústavodarnej moci v Slovenskej republike}

Základné podmienky výkonu ústavodarnej moci stanovuje čl. 72, čl. 86 písm. a), čl. 84 ods. 4 (t. j. procesné podmienky)

\section{Limity výkonu ústavodarnej moci}

\begin{tabular}{|c|c|c|c|c|}
\hline & Interné limity & & Externé limity & \\
\hline & Procesné & Substantívne & Procesné & Substantívne \\
\hline \multirow{2}{*}{$\begin{array}{c}\text { Explicitné } \\
\text { limity }\end{array}$} & \multirow{2}{*}{$\begin{array}{l}\text { Čl. } 7 \text { ústavného zákona } \\
\text { č. } 227 / 2002 \text { Z. z. }\end{array}$} & Čl. 99 ods. 1 & \multirow{2}{*}{ - } & \multirow{2}{*}{$\begin{array}{l}\text { L'udskoprávne medziná- } \\
\text { rodné záväzky SR (skrz. } \\
\text { čl. } 1 \text { ods. } 2 \text { a čl. } 12 \text { ods. } 1 \text { ) }\end{array}$} \\
\hline & & Čl. 12 ods. 1 & & \\
\hline \multirow{4}{*}{$\begin{array}{c}\text { Implicitné } \\
\text { limity }\end{array}$} & \multirow{4}{*}{ - } & $\begin{array}{c}\text { Kvalitatívne } \\
\text { kritériá } \\
\text { existencie ústavy } \\
\text { ako základného } \\
\text { zákona štátu }\end{array}$ & \multirow{4}{*}{ - } & Prirodzené právo* \\
\hline & & $\begin{array}{c}\text { Možnost' } \\
\text { opätovnej } \\
\text { aktivácie } \\
\text { ústavodarnej } \\
\text { moci* } \\
\end{array}$ & & $\begin{array}{l}\text { Dodržiavanie } \\
\text { medzinárodných } \\
\text { záväzkov SR } \\
\text { (čl. } 1 \text { ods. } 2 \text { ) }\end{array}$ \\
\hline & & \multirow{2}{*}{$\begin{array}{c}\text { Implicitné } \\
\text { materiálne jadro } \\
\text { Ústavy SR } \\
\text { (PL. ÚS } \\
\text { 21/2014) }\end{array}$} & & $\begin{array}{l}\text { Požiadavky plynúce } \\
\text { z členstva SR } \\
\text { v medzinárodných } \\
\text { organizáciách }\end{array}$ \\
\hline & & & & $\begin{array}{l}\text { Supranacionálne limity } \\
\text { (právo EÚ a jeho } \\
\text { efektivita) }\end{array}$ \\
\hline
\end{tabular}

*hypotetické limity 